\title{
The C4 Atriplex halimus vs. the C3 Atriplex hortensis: Similarities and Differences in the Salinity Stress Response
}

\author{
Roberta Calone*(D), Antonio Cellini (D), Luigi Manfrini (D), Carla Lambertini (D), Paola Gioacchini, Andrea Simoni \\ and Lorenzo Barbanti $(\mathbb{D}$
}

check for

updates

Citation: Calone, R.; Cellini, A.; Manfrini, L.; Lambertini, C.;

Gioacchini, P.; Simoni, A.; Barbanti, L.

The C4 Atriplex halimus vs. the C3 Atriplex hortensis: Similarities and Differences in the Salinity Stress Response. Agronomy 2021, 11, 1967. https://doi.org/10.3390/

agronomy11101967

Academic Editor: Roberto Barbato

Received: 2 August 2021

Accepted: 22 September 2021

Published: 29 September 2021

Publisher's Note: MDPI stays neutral with regard to jurisdictional claims in published maps and institutional affiliations.

Copyright: (c) 2021 by the authors. Licensee MDPI, Basel, Switzerland. This article is an open access article distributed under the terms and conditions of the Creative Commons Attribution (CC BY) license (https:// creativecommons.org/licenses/by/ $4.0 /)$.
Department of Agricultural and Food Sciences, Alma Mater Studiorum, University of Bologna, Viale Fanin 44, 40127 Bologna, Italy; antonio.cellini2@unibo.it (A.C.); luigi.manfrini@unibo.it (L.M.); carla.lambertini@unibo.it (C.L.); paola.gioacchini@unibo.it (P.G.); andrea.simoni@unibo.it (A.S.); lorenzo.barbanti@unibo.it (L.B.)

* Correspondence: roberta.calone3@unibo.it; Tel.: +39-05-1209-6643

\begin{abstract}
Soil properties and the ability to sustain agricultural production are seriously impaired by salinity. The cultivation of halophytes is seen as a solution to cope with the problem. In this framework, a greenhouse pot experiment was set up to assess salinity response in the perennial C4 species Atriplex halimus, and in the following three cultivars of the annual C3 Atriplex hortensis: green, red, and scarlet. The four genotypes were grown for 35 days with water salinity (WS) ranging from 0 to $360 \mathrm{mM} \mathrm{NaCl}$. Plant height and fresh weight (FW) increased at $360 \mathrm{vs.} 0 \mathrm{WS}$. The stomatal conductance (GS) and transpiration rate (E) were more severely affected by salinity in the $\mathrm{C} 4$ A. halimus than in the C3 species A. hortensis. This was reflected in a lower leaf water potential indicating stronger osmotic adjustment, and a higher relative water content associated with more turgid leaves, in A. halimus than A. hortensis. In a PCA including all the studied traits, the GS and E negatively correlated to the FW, which, in turn, positively correlated with Na concentration and intrinsic water use efficiency (iWUE), indicating that reduced gas exchange associated with $\mathrm{Na}$ accumulation contributed to sustain iWUE under salinity. Finally, FTIR spectroscopy showed a reduced amount of pectin, lignin, and cellulose under salinity, indicating a weakened cell wall structure. Overall, both species were remarkably adapted to salinity: From an agronomic perspective, the opposite strategies of longer vs. faster soil coverage, involved by the perennial A. halimus vs. the annual $A$. hortensis cv. scarlet, are viable natural remedies for revegetating marginal saline soils and increasing soil organic carbon.
\end{abstract}

Keywords: halophytes; gas exchanges; chlorophyll fluorescence; FTIR spectroscopy; element content; C:N ratio; electrolyte leakage

\section{Introduction}

The global population is growing at a rate of $1.1 \%$ per year and it is with $95 \%$ certainty that by 2050 it will reach between 9.4 and 10.1 billion people [1]. Recent projections, which use 2014 as a baseline, estimate that crop production should increase by $25-70 \%$ to meet food demand in 2050 [2]. Agricultural topsoil and soil organic carbon (SOC) are key ingredients for intensive food production [3-5]. SOC, indeed, plays a crucial role in the maintenance of soil health and productivity, due to its significant contribution to the physical, chemical, and biological properties of soil [6]. However, besides enhancing crop yield, SOC can act either as a source or a sink of atmospheric $\mathrm{CO}_{2}$, and thereby, can influence the global process of climate change [7].

Soil holds about $80 \%$ (2500 GT) of the terrestrial carbon stock. Of this, nearly $1550 \mathrm{GT}$ are in the form of SOC, and the remaining in the form of soil inorganic carbon (SIC), that mainly consists of elemental carbon and carbonate rocks such as calcite, dolomite, and gypsum. The soil carbon reserve is around three times that currently found in the 
atmosphere (800 GT) and four times that fixed in living plants and animals (560 GT). Only oceans have a larger carbon pool (about 38,400 GT), mostly in the inorganic form [8].

Over the last 10,000 years, however, the conversion of semi-natural or natural ecosystems into human-managed agro-ecosystems has caused a 50-75\% depletion of their carbon stock, with around 135 GT C released into the atmosphere [9,10].

Nevertheless, a recent study estimated that the soil carbon capacity for $\mathrm{C}$ sequestration can be expanded up to 1.45-3.44 GT C per year (around 5.3-12.6 $\mathrm{GT} \mathrm{CO}_{2}$ ) [11]. Due to this large carbon storage capacity, increasing atmospheric $\mathrm{CO}_{2}$ sequestration into long-life soil carbon is considered one of the most cost-effective solutions to combat climatic changes, contrast land degradation, and ensure food security [12].

Soil organic carbon content is a function of $C$ input and of its turnover. The main sources of SOC include crop residues, dead roots, and livestock manure; the decomposition of this organic matter (SOM) is mainly driven by soil microorganisms such as bacteria and fungi. The processes of carbon gain and storage, however, are affected by numerous factors including soil texture and $\mathrm{pH}$, irrigation and management practices, and several environmental factors such as high temperature, drought, salinity, etc. [13]. Consequently, the implementation of soil carbon sequestration strategies requires tailored options accounting for site-specific trade-offs and management opportunities.

As secondary soil salinisation is expanding worldwide with a rate of 2 Mha per year [14], there is a growing interest in exploring the potential of saline lands for carbon sequestration and storage. Indeed, the revegetation of saline areas can sequester substantial amounts of carbon [15], besides providing important ecosystemic benefits as wildlife habitats, biodiversity pools, and land regreening for grazing [16].

In saline soils, generally, the SOC content is lower than in non-saline soil, mainly due to sparser plant cover and lower microbial activity [17], which implies a reduced input of organic matter and slower decomposition rates [18].

On the other hand, SIC in the form of carbonate salts is higher in sodic and saline-sodic soils, while soil C loss due to microbial respiration and leaching may be much lower than in low salinity environments [19].

Hence, revegetating these areas with salt-tolerant crops can increase organic matter deposition and enhance SIC dissolution through their root respiration [20,21], and can aid in the maintenance of soil structure and SOC accumulation [22,23]. Additionally, growing halophytes as food and fodder crops could, at the same time, indirectly contribute to the atmospheric carbon mitigation by reducing deforestation to create new cropland [24].

The choice of halophyte species for saline area cultivation will depend on their salt tolerance level, agronomic value, ease of cultivation, water and nutrient requirement, and biomass potential.

In a previous study [25], the perennial C4 shrub Atriplex halimus resulted as the most salt tolerant species among six wild halophytes common in the Mediterranean area.

The wide range of salt stress responses described in Atriplex spp., indeed, makes this genus an attractive taxon for saline land reclamation and SOC accumulation in highly disturbed areas, as also proposed in other studies [26-30].

In this study, we compare the performance of the C4 Atriplex halimus L. with that of a closely related species, the C3 annual Atriplex hortensis L. Plenty of studies have investigated the two species taken separately, but little has been done to compare their mechanisms of salt tolerance and understand which conditions are more suitable for one species or for the other.

Atriplex halimus is a xerohalophytic shrub common in the Mediterranean basin. This species has been investigated for its ability to ameliorate soil properties and enhance carbon sequestration [30-34], restore highly calcareous sodic soil [35], improve degraded rangeland [36-38], remove heavy metals and salts from contaminated soil [34,39-44], and sustain the growth of consociated salt sensitive crops [45,46]. Atriplex halimus leaves were also traditionally used as a food dressing for their salty flavour [35]. However, their consumption mainly occurred at times when other sources of food were unavailable [32]. 
Atriplex hortensis, also known as orach or mountain spinach, is a species adapted to brackish marshes in temperate environments. It is a sodium-accumulating halophyte $[47,48]$ studied for saline soil phytoremediation [42,49] and, above all, as a leafy vegetable for the human diet thanks to its high nutritional value and medicinal properties [50-53].

The goal of the present study is to compare these two used halophytes, in order to evaluate their biomass production, carbon content, and $\mathrm{Na}$ accumulation capacity, and determine how physiological traits are shaped by salt tolerance in two species that are closely related but very different in their life cycle and photosynthetic pathway. We selected a red, a scarlet and a green cultivar of $A$. hortensis and a common $A$. halimus species for our experiment.

\section{Materials and Methods}

\subsection{Acronyms}

The acronyms used in this study are defined as follows: fresh weight (FW), dry weight (DW), plant height (PH), electrolyte leakage (EL), specific leaf area (SLA), carbon isotope ratio $\left(\delta^{13} \mathrm{C}\right)$, net photosynthesis $(\mathrm{A})$, leaf transpiration $(\mathrm{E})$, stomatal conductance $(\mathrm{GS})$, spad value (SPAD), effective quantum yield efficiency of PSII (ФPSII), level of photochemical quenching of PSII (qP), PSII maximum efficiency $\left(\mathrm{Fv}^{\prime} / \mathrm{Fm}^{\prime}\right)$, electron transport rate (ETR), leaf relative water content (RWC), leaf water potential (LWP), and intrinsic water use efficiency (iWUE).

\subsection{Plant Material and Growth Conditions}

The experiment was carried out at the Department of Agricultural and Food Sciences (DISTAL), University of Bologna, Italy. Commercial seeds of Atriplex halimus, A. hortensis cv. red, $A$. hortensis cv. Scarlet, and $A$. hortensis cv. green were purchased online from The Original Garden (Valladolid, Spain) and Seedaholic (Galway, Ireland) online shops.

Seeds were surface-sterilised by immersion in a 3\% sodium hypochlorite solution for $2 \mathrm{~min}$, rinsed in deionised water for $5 \mathrm{~min}$, and dried at room temperature. Prior to sowing, A. halimus seeds were soaked for $12 \mathrm{~h}$ in deionised water and, thereafter, scarified by manual bract removal in order to interrupt dormancy. Due to their slower germination, seeds of $A$. halimus were sown 30 days before $A$. hortensis spp. seeds.

Seeds were sown manually in plastic seedling trays and placed into a growth chamber with a 16/8-hour light/dark cycle, day/night temperatures of $27 / 22{ }^{\circ} \mathrm{C}$ and $70-80 \%$ relative humidity. The trays were dampened with distilled water once per day.

After germination, plantlets of similar size (4 leaves stage) were transplanted into plastic pots of 3-litre volume (1 plant/pot) filled with a mix of river sand, peat moss $(26 \%$ organic carbon, $\mathrm{pH}_{\mathrm{H}_{2} \mathrm{O}}=5.8$, and salt content $\left.=1.6 \mathrm{~g} \mathrm{~L}^{-1}\right)$, and perlite $(7: 2: 1 \mathrm{v} / \mathrm{v})$.

Pots were transferred to a greenhouse, placed over benches, and irrigated automatically three times per week with $200 \mathrm{~mL}$ of fresh water up to the beginning of the salt treatment, to ensure adequate substrate moisture. Ammonium nitrate (N, 26\%) was added at $0.1 \mathrm{~g} \mathrm{pot}^{-1}$ prior to seedling transplant; a second dose was supplied mid-experiment by placing the granular fertiliser directly on substrate surface prior to watering.

In the greenhouse, temperatures ranged between $22.2 \pm 1.1$ and $27.7 \pm 16^{\circ} \mathrm{C}$, and $\mathrm{RH}$ between $42 \pm 4 \%$ and $82 \pm 3.7 \%$. Photosynthetically active radiation (PAR) of $200 \mathrm{~mol} \mathrm{~m}^{-2} \mathrm{~s}^{-1}$ was provided by high pressure sodium lamps with a 16-hour light and 8-hour dark cycle.

\subsection{Treatments and Experimental Design}

In all plants, excluding those grown at $0 \mathrm{mM} \mathrm{NaCl}$, salt treatments were started 20 days after transplanting, on the 20 July, when plants had six to eight leaves. Salt stress was induced by incremental increases of $90 \mathrm{mM}$ in the irrigation water every 3 days, until the final concentrations of 90,180 , and $360 \mathrm{mM} \mathrm{NaCl}$ were reached on the 27 July. 
The amount of salt added to water (TSS, $\mathrm{g}_{\mathrm{NaCl}} \mathrm{L}^{-1} \mathrm{H}_{2} \mathrm{O}$ ) to reach the four salinity levels $\left(\mathrm{EC}_{\mathrm{w}}, \mathrm{dS} \mathrm{m}^{-1}\right)$ was calculated according to Equation (1) as follows:

$$
\mathrm{TSS}=\mathrm{EC}_{\mathrm{w}} * 0.640
$$

A total of $200 \mathrm{ml}$ of water solution was automatically distributed to each pot three time per week until the end of the experiment.

The 4 halophyte genotypes (HG) $\times 4$ water salinity levels (WS), totalling $16 \mathrm{com}$ binations, were set up with 8 randomised replicates, totalling 128 pots. Four plants per treatment were used for non-destructive measurements and final harvest, while other four plants were used for destructive measurements (SLA, EL, WP, RWC), as below described.

The four genotypes were abbreviated AH (A. halimus), AR (A. hortensis red), AS (A. hortensis scarlet), and AG (A. hortensis green). The four water salinity treatments were named Ctrl, WS90, WS180, and 360 WS.

\subsection{Growth and Yield Assessment}

On the 31 August, 35 days after salt stress initiation (DAS), four plants per each treatment were randomly selected and harvested. Shoots were separated from roots and weighed to determine the plant fresh weight $\left(\mathrm{FW}, \mathrm{g} \mathrm{plant}^{-1}\right)$ and the plant height $(\mathrm{PH}, \mathrm{cm})$. Shoot samples were oven-dried at $60^{\circ} \mathrm{C}$ and weighed to determine the dry weight (DW, g plant $^{-1}$ ). Specific leaf area (SLA, $\mathrm{cm}^{2} \mathrm{~g}^{-1}$ ) was measured one day before harvest on four plants per treatment by dividing the leaf area of three randomly selected leaves by their dry weight.

\subsection{Plant Water Relations}

Water potential $(\Psi \mathrm{w})$ was measured on a leaf disk from the uppermost fully expanded leaf, using the WP4-C dewpoint potentiometer (METER Group, Pullman, WA, USA). Leaf cuts were stored in sealed plastic cups and measurements were started within a short time of sampling [54]. Concurrently, leaf relative water content (RWC, \%) was determined on the same leaf: a small disc of $2 \mathrm{~cm}$ diameter was cut from the leaf and weighed to determine fresh weight (FW). Then, it was put in a 15-millilitre vial with distilled water in the dark and, after $24 \mathrm{~h}$, the turgid weight (TW) was measured. The sample was finally oven-dried at $105{ }^{\circ} \mathrm{C}$ for $24 \mathrm{~h}$ to assess the dry weight (DW). The RWC (\%) was calculated according to Equation (2) as follows [55]:

$$
\mathrm{RWC}=\frac{\mathrm{FW}-\mathrm{DW}}{\mathrm{TW}-\mathrm{DW}} \times 100
$$

All the plant water relation measurements were performed at 7 and 27 days after salt stress initiation (DAS).

\subsection{Electrolyte Leakage}

To determine cell membrane permeability, a leaf sample of $2 \mathrm{~cm}^{2}$ was cut from the upper fully expanded leaf, rinsed 3 times with demineralised water and immersed into distilled water in 10-millilitre flasks. Electrical conductivity (EC) was measured after $2 \mathrm{~h}$ of floating at room temperature using a conductivity meter.

Total conductivity was obtained by repeating the procedure after keeping the flasks in an oven $\left(90^{\circ} \mathrm{C}\right)$ for $2 \mathrm{~h}$. Results were expressed as a percentage of total conductivity. The measurement was executed one day before harvest on four plants per treatment.

\subsection{Leaf Gas Exchange and Chlorophyll Fluorescence}

Leaf transpiration ( $\mathrm{E}$, in $\mathrm{mmol} \mathrm{m} \mathrm{m}^{-2} \mathrm{~s}^{-1}$ ), stomatal conductance (GS, in $\mathrm{mmol} \mathrm{m}^{-2} \mathrm{~s}^{-1}$ ),

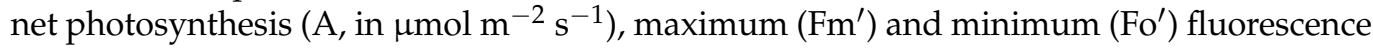
with light-adapted leaf, and steady state fluorescence $(\mathrm{Fs})$ were measured using a portable photosynthesis system (Li-Cor 6400, LI-COR Biosciences, Lincoln, NE, USA), after setting 
a $\mathrm{CO}_{2}$ concentration similar to the external environment (400 ppm), and a LED light source $(90 \%$ red and $10 \%$ blue) similar to the natural irradiance occurring inside the greenhouse $\left(200 \mu \mathrm{mol} \mathrm{m} \mathrm{m}^{-2} \mathrm{~s}^{-1}\right)$. The chamber block temperature was $28 \pm 2{ }^{\circ} \mathrm{C}$ and the leaf temperature inside the sensor head was $28 \pm 3^{\circ} \mathrm{C}$. The chamber oxygen concentration was equal to the external environment.

The effective quantum yield efficiency of PSII (ФPSII), which represents the capacity for photon energy absorbed by photosystem II (PSII) to be utilised in photochemistry under light-adapted conditions, was calculated as $\left(\mathrm{Fm}^{\prime}-\mathrm{Fs}\right) / \mathrm{Fm}^{\prime}$. The $\Phi$ PSII was broken down in its two components, as follows: the level of photochemical quenching of PSII (qP) and the PSII maximum efficiency $\left(\mathrm{Fv}^{\prime} / \mathrm{Fm}^{\prime}\right)$. The $\mathrm{qP}$, which is related to the actual fraction of photochemically active PSII reaction centres, was calculated as $\left(\mathrm{Fm}^{\prime}-\mathrm{Fs}\right) /\left(\mathrm{Fm}^{\prime}-\mathrm{Fo}^{\prime}\right)$. The $\mathrm{Fv}^{\prime} / \mathrm{Fm}^{\prime}$ was calculated as $\left(\mathrm{Fm}^{\prime}-\mathrm{Fo}^{\prime}\right) / \mathrm{Fm}^{\prime}$ and describes the maximum operating efficiency in the light adapted state, with any decrease in this parameter reflecting an increase in non-photochemical quenching.

The intrinsic water use efficiency (iWUE, $\mu \mathrm{mol} \mathrm{CO} \mathrm{Cmol}^{-1} \mathrm{H}_{2} \mathrm{O}$ ) was determined as the molar ratio between photosynthetic assimilation of $\mathrm{CO}_{2}(\mathrm{~A})$ and water loss by transpiration (E). All gas exchange and fluorescence parameters were measured at 7 and 27 days after salt stress initiation (DAS) on the youngest fully expanded leaf of four plants per treatment.

\subsection{Mineral Elements}

Dry samples of plant shoots were ground, and the concentration of the main elements ( $\mathrm{Na}, \mathrm{K}, \mathrm{Ca}, \mathrm{Mg}$ and $\mathrm{P}$ ) was quantified using Inductively Coupled Plasma Spectrometry (ICP-OES) (Spectro Arcos, Ametek, Kleve, Germany). Three analyses per treatment were performed.

\subsection{Total Carbon and Nitrogen Content and Carbon Isotope Ratio}

The $\mathrm{C}$ and $\mathrm{N}$ concentration of the dry and ground shoot samples was determined using the Flash 2000 elemental analyser (Thermo Fisher Scientific, Waltham, MA, USA).

The stable carbon isotope ratio was measured on the same sample using Continuous Flow-Isotope Ratio Mass Spectrometry (CF-IRMS), by introducing the combustion gases $\left(\mathrm{CO}_{2}\right)$ from the elemental analyser into the Isotope Ratio Mass Spectrometer (IRMS, Delta V Advantage, Thermo Fisher Scientific).

The $\mathrm{C}$ isotope ratio was expressed as $\delta^{13} \mathrm{C}$ values (\%o) according to following formula:

$$
\delta{ }^{13} \mathrm{C} \%=\left[\frac{\mathrm{R} \text { sample }}{\mathrm{R} \text { standard }}-1\right] \times 1000
$$

where $\mathrm{R}$ sample and $\mathrm{R}$ standard are the ${ }^{13} \mathrm{C} /{ }^{12} \mathrm{C}$ ratios of sample and of the international standard (Vienna Pee Dee Belemnite standard, VPDB), respectively. Three analyses per treatment were performed.

\subsection{Spectroscopic Characterisation}

FT-IR spectra of samples were recorded by using a Bruker Tensor FT-IR instrument (Bruker Optics, Ettlingen, Germany) provided with an accessory for analysis in total reflectance attenuated (ATR), single reflection and a $45^{\circ}$ angle of incidence (Specac Quest ATR, Specac Ltd., Orpington, Bromley, UK).

The spectra were acquired from 4000 to $400 \mathrm{~cm}^{-1}$, with a spectral resolution of $4 \mathrm{~cm}^{-1}$ and 64 scans. Offset normalisation was performed to adjust the baseline and move the spectra intensities so that the minimum absorbance value was 0 . A background against air before each measurement was performed. Spectra were processed using the Grams/386 spectroscopic software (version 6.00, Galactic Industries Corporation, Salem, NH, USA). 


\subsection{Statistical Analysis}

The data of the measured traits were submitted to two-way ANOVA for the two factors HG and WS, and the HG $\times$ WS interaction. The Tukey's honest significant difference (HSD) post hoc test at $p<0.05$ was used to indicate significant differences among ANOVA sources. The ANOVA results are reported in Tables S1-S3 of the Supplementary Materials.

To better highlight the key effects of the experiment, only the data from the two corner salinity treatments (Ctrl and $360 \mathrm{WS}$ ) are reported in the Results; the intermediate salinity levels (90 and $180 \mathrm{WS}$ ) exhibited an intermediate behaviour.

We investigated the relationships among traits measured at 27 DAS by computing the pairwise Spearman's rank correlation coefficients $(\varrho)$, and then testing their significance with $\alpha=0.05$ [56].

A principal component analysis (PCA) was carried out on the physiological data collected at harvest to summarise with a multivariate approach the performances of the four genotypes under Ctrl and 360 WS treatment.

The principal components (PCs) were obtained from centred and scaled quantitative variables, through diagonalisation of the correlation matrix and extraction of the associated eigenvectors and eigenvalues. All the measured traits were set as active quantitative variables, while the four halophyte genotypes $(\mathrm{AH}, \mathrm{AG}, \mathrm{AR}, \mathrm{AS})$ and the two treatments (Ctrl and 360 WS) were used as supplementary categorical variables, i.e., variables that were not used in the computation of PCs.

All the statistical analyses were performed with the R 6.3.6 statistical software, using Car [57] and Emmeans [58] packages for the analysis of variance and post hoc test, and the FactoMineR package for principal component analysis [59]. Charts were created with the ggplot2 [60] and corrplot [61] R packages.

\section{Results}

\subsection{Plant Growth}

Under the Ctrl conditions, Atriplex hortensis cv. green and scarlet exhibited the highest fresh weight (FW), while A. hortensis red showed the lowest FW. All the four genotypes, however, recorded a significant biomass increase under $360 \mathrm{WS}$, with the greatest increment in A. hortensis red and scarlet ( $+38 \%$ and $+33 \%$, respectively) (Figure 1A). Despite the increased FW, the plant DW did not show a significant HG $\times$ WS interaction (Figure 1B), although the resulting effects of the two single factors were significant (Table S4 of the Supplementary Materials).

Under the Ctrl condition, the three A. hortensis cultivars had a similar and statistically higher plant height $(\mathrm{PH})$ than $A$. halimus (Figure 1C). The impact of salinity on $\mathrm{PH}$ was almost negligible in all the halophytes except $A$. hortensis $\mathrm{cv}$. red, which showed a significant PH decrease ( $-31 \%)$. Likewise, the three $A$. hortensis cultivars showed a statistically higher specific leaf area (SLA) than A. halimus under the control condition (Figure 1E). Under salinity, however, $A$ halimus did not undergo a significant SLA decrease, while $A$. hortensis green and scarlet showed higher, significant reductions ( $-35 \%$ and $-20 \%$, respectively).

Salinity induced a significant increase in leaf electrolyte leakage (EL) in all of the four halophytes (Figure 1D), with the highest increment in the two green-leaved genotypes, A. hortensis green $(+131 \%)$ and A. halimus $(+105 \%)$.

The three C3 A. hortensis genotypes showed a similar ( $-33 \%$ on average) and statistically lower (more negative) $\delta^{13} \mathrm{C}$ compared to the $\mathrm{C} 4 \mathrm{~A}$. halimus genotype (Figure $1 \mathrm{~F}$ ). The 360 WS induced a $\delta^{13} \mathrm{C}$ shift towards less negative values in the three $A$. hortensis genotypes with no effects, instead, in A. halimus. 

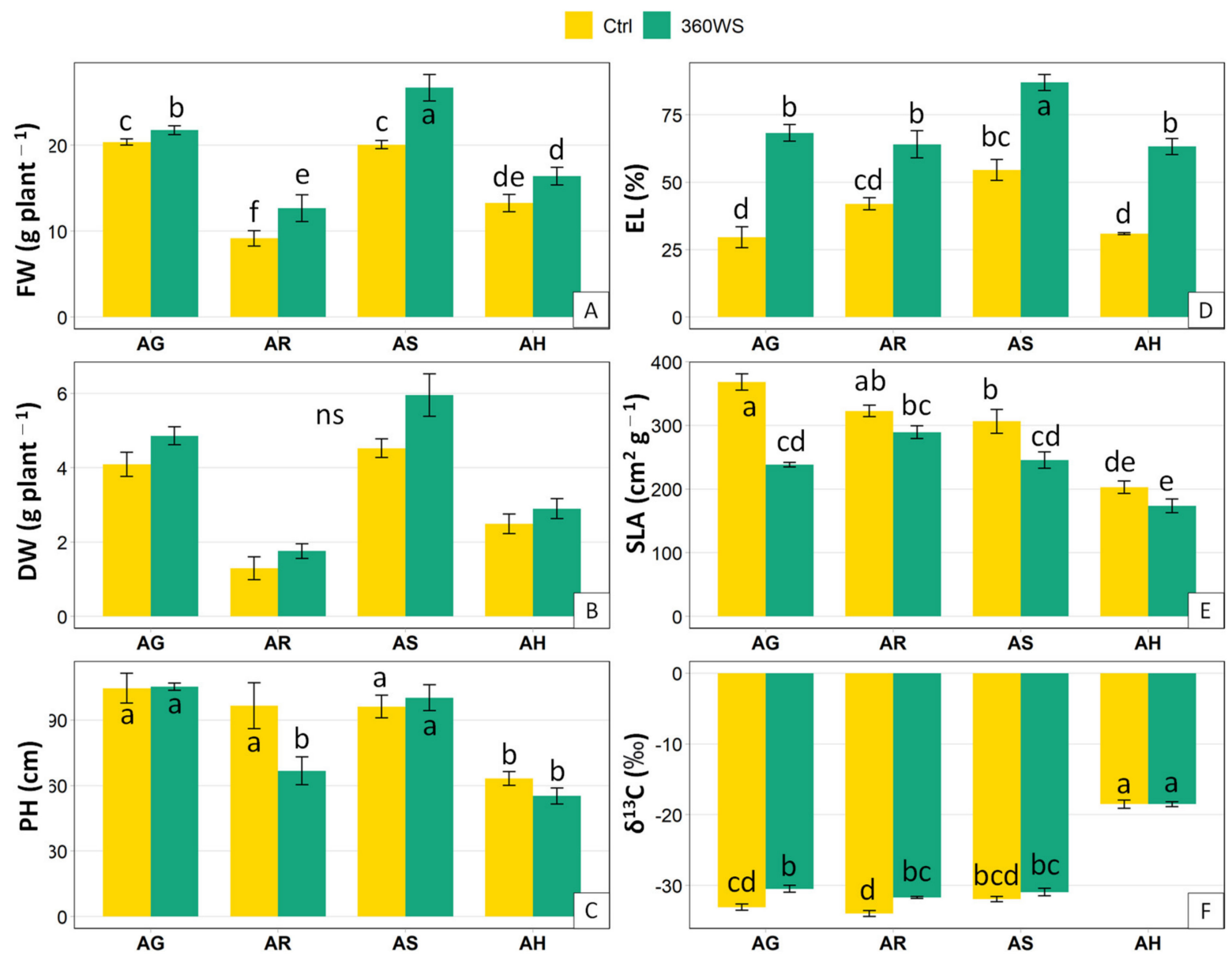

Figure 1. (A) Fresh weight, (B) dry weight, (C) plant height, (D) electrolyte leakage, (E) specific leaf area, and (F) ${ }^{13} \mathrm{C}$ isotope ratio under control (Ctrl) and $360 \mathrm{mM}$ water salinity (360 WS) in the four genotypes $A$. hortensis $\mathrm{cv}$. green (AG), A. hortensis cv. red (AR), A. hortensis cv. scarlet (AS), and A. halimus (AH). Vertical bars indicate standard error $(n=4)$. Different letters indicate significant differences at $p<0.05$.

\subsection{Photosynthesis and Leaf Gas Exchange}

Seven days after the salt stress initiation (7 DAS), the two genotypes showing the highest photosynthetic activity (A) under Ctrl, i.e., A. hortensis scarlet and green, were those recording the highest A drop under salinity ( $-32 \%$ and $-29 \%$, respectively; Figure 2A), while the other two genotypes had milder, non-significant A drops (Figure 2A).

The stomatal conductance (GS), on the contrary, decreased significantly in all of the four genotypes, with the sharpest drop in A. hortensis green, which was the genotype showing the highest GS under the Ctrl condition (Figure 2B). The plant transpiration (E) followed a similar pattern as the GS (Figure 2C,G). Salinity did not affect the chlorophyll content (SPAD value), whereas remarkable differences occurred among genotypes under Ctrl, with the highest SPAD values in A. hortensis scarlet (39.5), followed by A. halimus (28.9) (Figure 2D,H).

Twenty days later, at 27 DAS, the four genotypes did not show significant differences in A values between $\mathrm{Ctrl}$ and HWS (Figure 2E) with, however, a considerable drop in A values in A. hortensis scarlet compared to 7 DAS, especially under 360 WS. Under Ctrl, the stomatal conductance (GS) decreased in all three $A$. hortensis genotypes, while it remained almost unchanged in A. halimus (Figure 2F). As already observed at 7 DAS, the salinity significantly decreased the GS, with the greatest decrease in the two green-leaved genotypes, A. halimus $(-60 \%)$ and $A$. hortensis green $(-55 \%)$. Similarly, at 27 DAS, E dropped under Ctrl in all the three A. hortensis genotypes and increased in A. halimus (Figure $2 \mathrm{G}$ ). The effects of salinity 
on E were similar to that observed in the GS (Figure 2F). The SPAD value was not affected by salinity at 27 DAS (Figure $2 \mathrm{H}$ ), as it was not affected at 7 DAS.

Ctrl 360WS

7 DAS

27 DAS
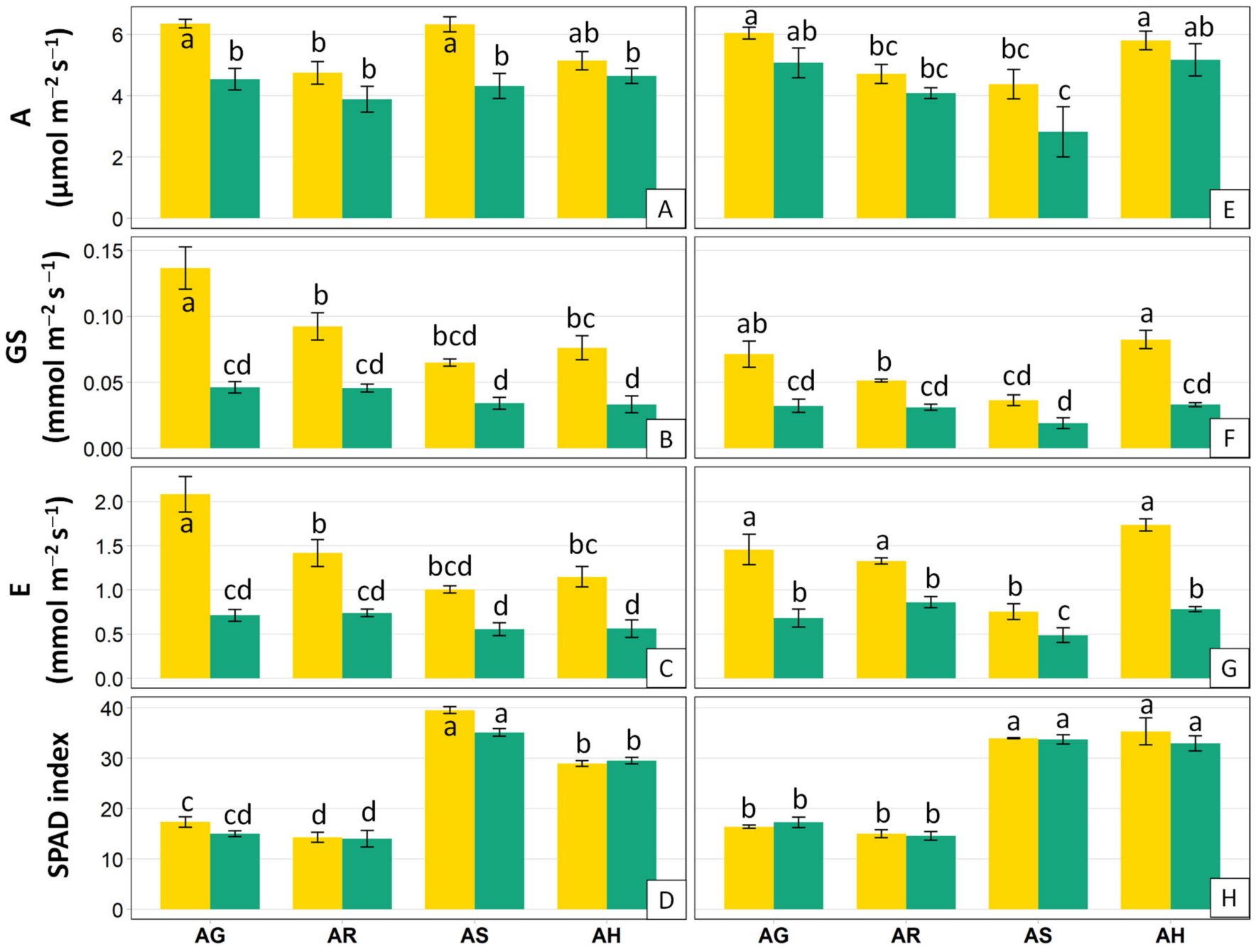

Figure 2. Photosynthetic activity (A), stomatal gas exchange (GS), transpiration rate (E) and, chlorophyll content (SPAD value) at 7 days after salt stress initiation (DAS) (A, B, C, D, respectively) and at 27 DAS (E, F, G, H, respectively) under control (Ctrl) and $360 \mathrm{mM}$ water salinity (360 WS) in the four genotypes A. hortensis cv. green (AG), A. hortensis cv. red (AR), A. hortensis cv. scarlet (AS), and A. halimus (AH). Vertical bars indicate standard error $(n=4)$. Different letters indicate significant differences at $p<0.05$.

\subsection{Chlorophyll Fluorescence}

At 7 DAS, the operating efficiency of PSII photochemistry (ФPSII) and its qP component, i.e., the level of photochemical quenching of PSII, did not yet show a significant HG $\times$ WS interaction, although the single effect of HG was. The same was observed for the electron transport rate (ETR) (Table S5 of the Supplementary Materials). The only fluorescence parameter recording a significant interaction between the two experimental factors was $\mathrm{Fv}^{\prime} / \mathrm{Fm}^{\prime}$, which is the second component of the $\Phi P S I I$ expressing the maximum efficiency of PSII photochemistry in the light $\left(\mathrm{Fv}^{\prime} / \mathrm{Fm}^{\prime}\right)$ (Figure 3B). Under the Ctrl condition, $\mathrm{Fv}^{\prime} / \mathrm{Fm}^{\prime}$ reached the highest value in A. hortensis green and scarlet. These latter, however, were the only two genotypes showing an $\mathrm{Fv}^{\prime} / \mathrm{Fm}^{\prime}$ decrease with 360 WS. 

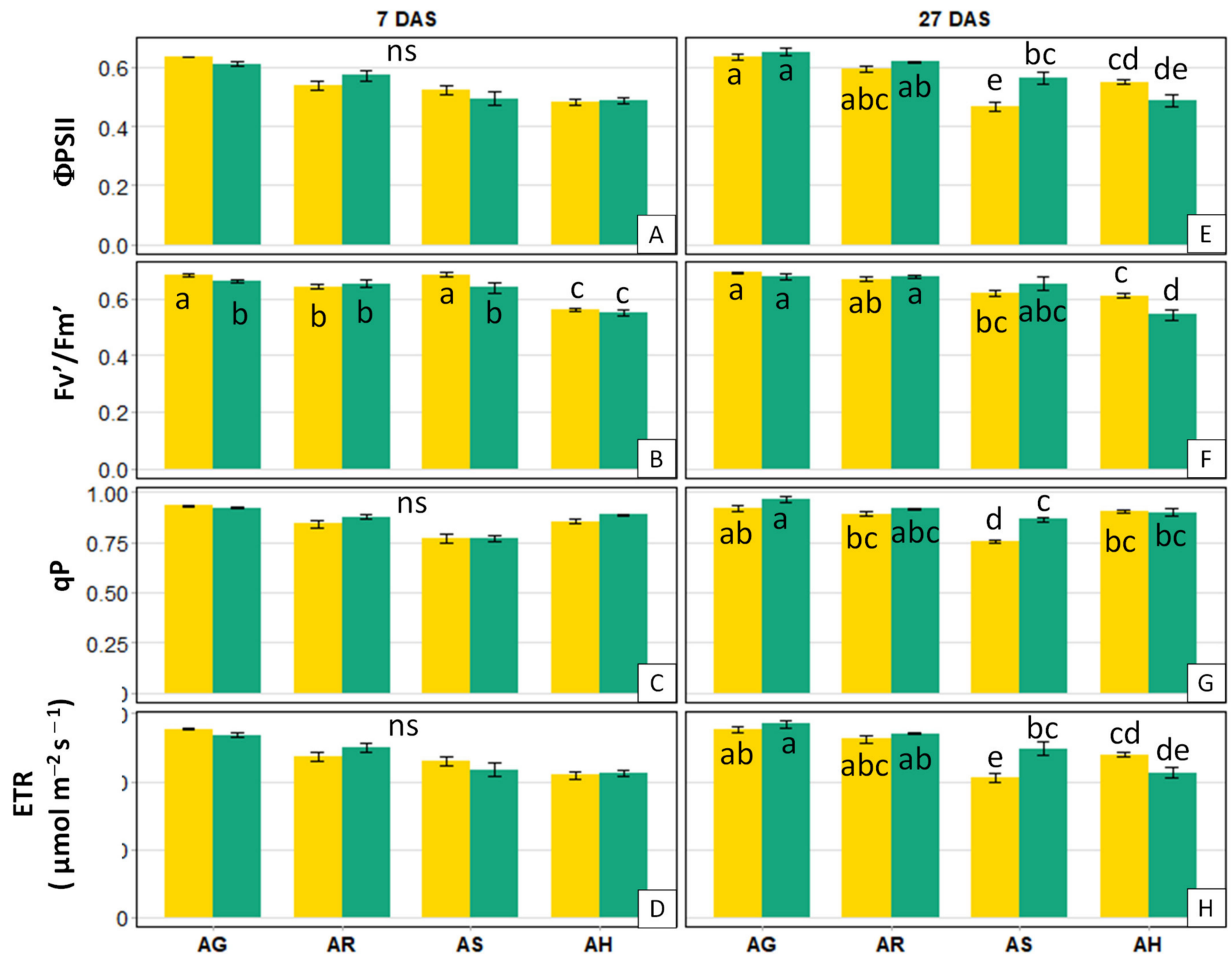

Figure 3. Operating efficiency of PSII photochemistry (ФPSII), maximum efficiency of PSII photochemistry in the light $\left(\mathrm{Fv}^{\prime} / \mathrm{Fm}^{\prime}\right)$, level of photochemical quenching of PSII (qP), and electron transport rare (ETR) at 7 days after salt stress initiation (A, B, C, D, respectively) and at 27 days after salt stress initiation (E, F, G, H, respectively) under control (Ctrl) and $360 \mathrm{mM}$ water salinity (360 WS) in the four genotypes A. hortensis cv. green (AG), A. hortensis cv. red (AR), A. hortensis cv. scarlet (AS), and A. halimus (AH). Vertical bars indicate standard error $(n=4)$. Different letters indicate significant differences at $p<0.05$.

The single WS factor, however, did not determine any significant changes in any of the four described fluorescence parameters.

At 27 DAS, instead, all the four fluorescence parameters presented a significant HG $\times$ WS interaction (Table S6 of the Supplementary Materials). In contrast to the other three genotypes, Atriplex hortensis scarlet was the sole genotype increasing the $\Phi$ PSII, $\mathrm{Fv}^{\prime} / \mathrm{Fm}^{\prime}$, and ETR under 360 WS (Figure 3E-G), while A. halimus decreased in $\mathrm{Fv}^{\prime} / \mathrm{Fm}^{\prime}$. In the other genotypes, 360 WS did not induce significant fluorescence changes compared to the Ctrl.

\subsection{Water Relations}

At 7 DAS, the plant relative water content (RWC) and intrinsic water use efficiency (iWUE) did not show any significant $\mathrm{HG} \times$ WS interaction, although the resulting effects of the two single factors were significant (Table S5 of the Supplementary Materials). The leaf water potential (WP) outlined narrow, yet significant, differences under Ctrl with the 
lowest value in A. halimus (Figure 4B). The 360 WS determined a WP decrease in all of the four genotypes, with the greatest reduction in A. hortensis scarlet and A. halimus ( $-154 \%$ and $-107 \%$, respectively).

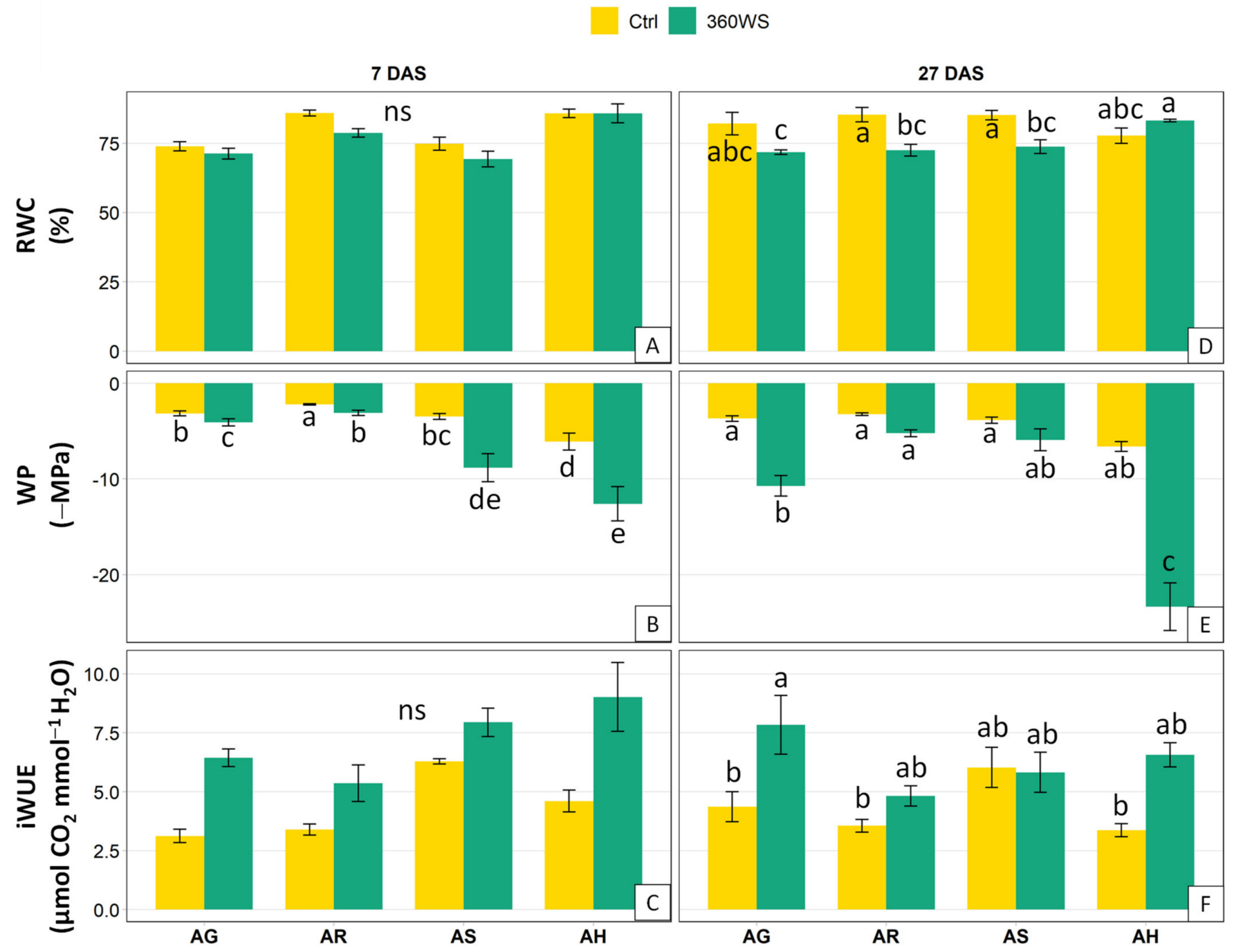

Figure 4. Leaf relative water content, leaf water potential, and intrinsic water use efficiency at 7 days after salt stress initiation (A, B, C, respectively) and at 27 days after salt stress initiation (D, E, F, respectively) under control (Ctrl) and $360 \mathrm{mM}$ water salinity (360 WS) in the four genotypes A. hortensis cv. green (AG), A. hortensis cv. red (AR), A. hortensis cv. scarlet (AS), and A. halimus (AH). Vertical bars indicate standard error $(n=4)$. Different letters indicate significant differences at $p<0.05$.

Twenty days later, at 27 DAS, the four genotypes had similar RWCs under Ctrl, but the 360 WS determined a RWC decrease in the two red-leaved halophytes $(A$. hortensis scarlet and $A$. halimus) (Figure 4D).

The WP exhibited similar values among the four genotypes under Ctrl, but the 360 WS determined a severe WP decrease in A. halimus and A. hortensis green $(-192 \%$ and $-254 \%$, respectively) and negligible drops in the two red-leaved species.

Under Ctrl, the iWUE result was similar among the four genotypes but the $360 \mathrm{WS}$ determined a iWUE increase in the two green-leaved species, although only in $A$. hortensis green this change was significant (Figure 4F).

\subsection{Element Vector Analysis}

The vector analysis combines changes in biomass and element concentration and content into a comprehensive picture of plant response to $\mathrm{Na}$ input (Figure 5A). 
High salinity (360 WS) did not determine a significant dry weight change in any of the four genotypes. Hence, the strong increase in the Na content and concentration may indicate an enhanced and selective uptake of this nutrient in all of the four Atriplex accessions, with no detrimental effect on overall plant growth.

Minor changes were also observed in the other elements. The potassium uptake appeared to be not limited by salinity (Figure 5B). However, $A$. hortensis cv. red showed a significant drop in the $\mathrm{K}$ concentration, indicating a possible dilution effect related to a plant DW increase, although the latter was not significant. $A$. hortensis cv. scarlet was the only genotype showing a strong K content increase with $360 \mathrm{WS}$, confirming that $\mathrm{K}$ availability was not limited by Na competition and a preferential K accumulation occurred in the plant.

Ca availability, instead, appeared to be more affected by salinity as all of the four genotypes showed a Ca concentration decrease (Figure 5B). This decrease may be interpreted as a symptom of $\mathrm{Na}$ antagonism, in those genotypes also showing a Ca content drop (A. halimus and A. hortensis cv. green), or dilution, as in the case of $A$. hortensis cv. scarlet and red, which showed the highest, although not significant, DW increase under 360 WS.

Three out of the four genotypes, as well, outlined a Mg concentration decrease that may be ascribed to $\mathrm{Na}$ antagonism in $A$. hortensis $\mathrm{cv}$. green (a significant $\mathrm{Mg}$ content decrease, too) or to a dilution effect in the case of A. halimus and A. hortensis cv. red (no Mg content decrease) (Figure 5C). In the case of A. hortensis cv. scarlet, again, the rise in Mg content combined with the steadiness in $\mathrm{Mg}$ concentration may be ascribed to a dilution effect.

Contrarily to the three cations, the P uptake appeared to be boosted by 360 WS (Figure 5C). In all of the four genotypes, indeed, the P content increased, with the highest accumulation in A. hortensis cv. scarlet. The lack of $\mathrm{P}$ concentration increases in A. hortensis $\mathrm{cv}$. red and green may indicate that the increase in the $\mathrm{P}$ content was proportional to the dry biomass increase, thereby resulting in no significant change in element concentration.

Nitrogen content increased with salinity, although the increase was significant only in A. hortensis cv. red and scarlet (Figure 5D). As before, the unchanged value in N concentration in all of the four genotypes may indicate that the $\mathrm{N}$ content increase was proportional to the dry biomass increase, thereby resulting in no significant change in element concentration.

Finally, the carbon content increased in all of the genotypes except $A$. halimus (Figure 5D). The observed drop in element concentration in A. halimus and in A. hortensis cv. red and scarlet may indicate that the increase in the biomass was proportionally higher that the increase in the element content, resulting in a $\mathrm{C}$ concentration drop.

Thus, among the four genotypes, A. hortensis cv. scarlet stands out for its higher content of $\mathrm{K}, \mathrm{P}$, and $\mathrm{Mg}$ as a likely result of selective uptake as osmoregulation compounds. $A$. hortensis $\mathrm{cv}$. red, instead, is characterised by the higher $\mathrm{N}$ and $\mathrm{Na}$ increase. Compared to the former two genotypes, A. halimus and A. hortensis cv. green did not show a significant change in neither the $\mathrm{K}$ nor $\mathrm{N}$ content and concentration (Figure 5E). 


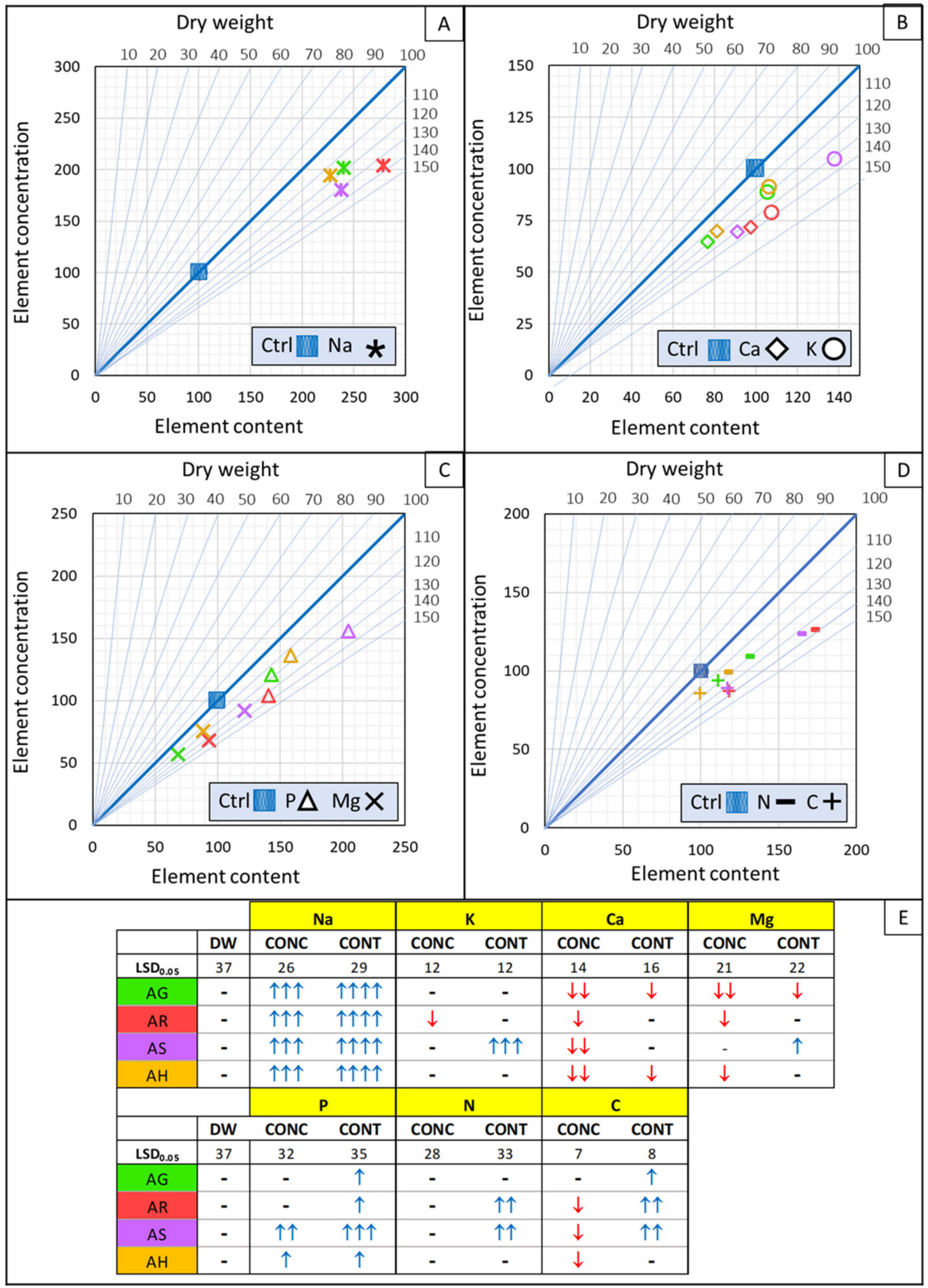

Figure 5. Vector analysis showing directional changes in Atriplex spp. dry weight and (A) Na content and concentration, (B) $\mathrm{K}$ and Ca content and concentration, (C) Mg and P content and concentration, (D) $\mathrm{N}$ and C content and concentration. Dry weight and element content and concentration are expressed as relative data with respect to the Ctrl treatment, which is set at $100 \%$ and is indicated by a blue square; the colours of the element symbols are related to the four genotypes, as shown in the ensuing interpretation of the directional changes in relative dry weight (DW) and element concentration and content with respect to the reference treatment (Ctrl) (E). Upwards and downwards arrows indicate significant changes, and (-) indicates insignificant changes. The number of arrows indicate an increasing amplitude of the variation (from $>1$ to $>4$ LSD). 


\subsection{Physiological Traits Relationships and Results of the Multivariate Analysis}

The plant fresh weight (FW) and electrolyte leakage (EL) results were negatively correlated with the transpiration rate $\mathrm{E}(\varrho=-0.52$ and $\varrho=-0.85$, respectively) and stomatal conductance (GS) ( $\varrho=-0.37$ and $\varrho=0.86$, respectively), suggesting that, although the gas exchange reduction had a detrimental effect on the plant membrane stability, it represents a key strategy adopted by the plant to maintain its growth (Figure 6). Indeed, the positive correlation between the FW and EL $(\varrho=0.52)$ indicates that increased membrane permeability did not hamper plant growth.

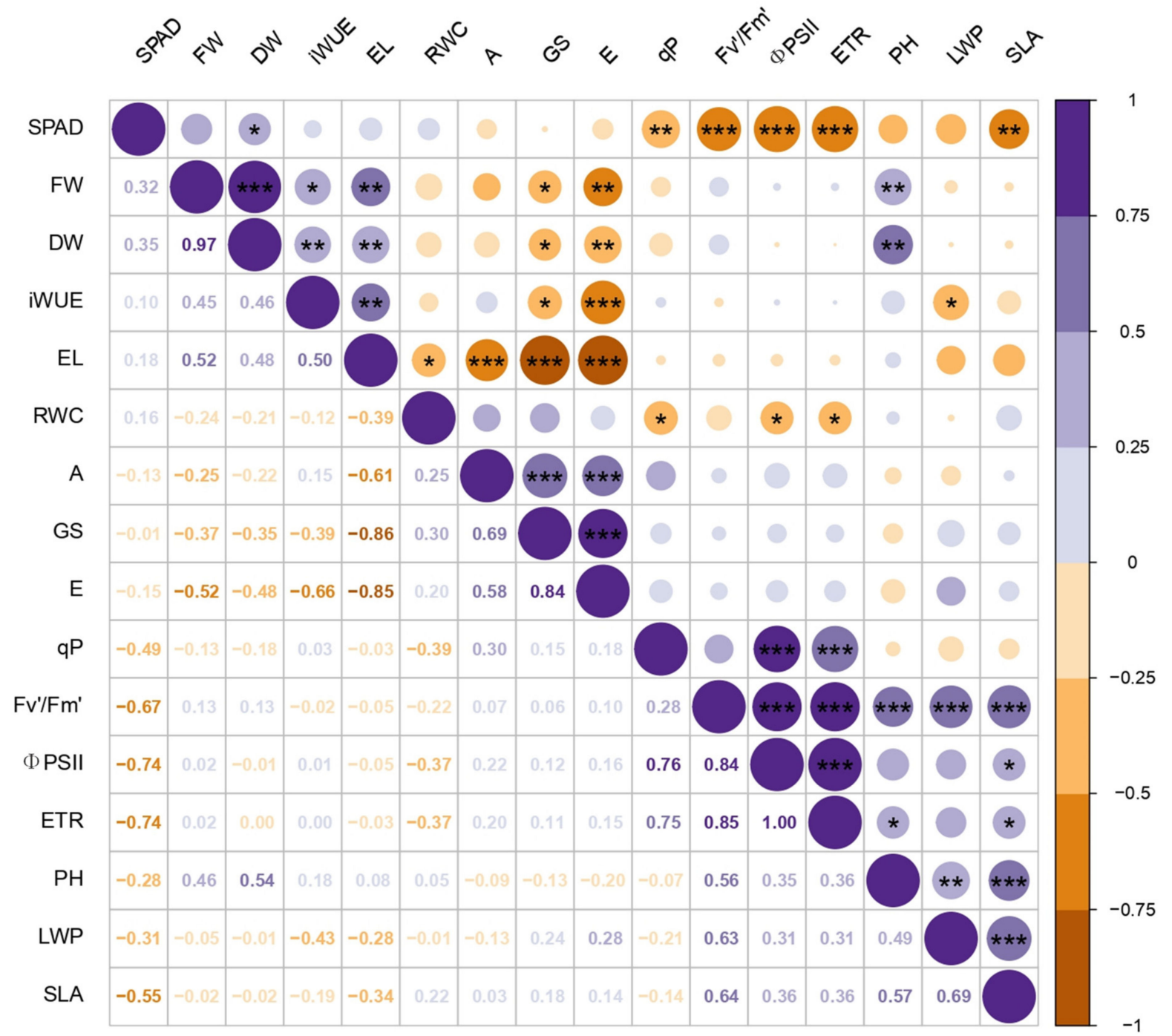

Figure 6. Pairwise Spearman's rank correlation coefficients calculated for the surveyed traits. Above the diagonal: graphical representation, with the colours and size of the circles referring to the direction and intensity of the correlations, while the symbols *,***** express significant correlations at $p<0.05,0.01$, and 0.001 Below the diagonal: numerical coefficients.

Consistently, the plant intrinsic water use efficiency (iWUE) outlined a negative association with the plant GS $(\varrho=-0.39), \mathrm{E}(\varrho=-0.66)$, and leaf water potential (LWP) $(\varrho=-0.43)$, meaning that a decrease in these parameters allowed plant growth to be sustained under conditions of reduced water availability.

These observations are further corroborated by the negative, although bland, correlation between the leaf RWC and qP $(\varrho=-0.39)$, ФPSII $(\varrho=-0.37)$, and ETR $(\varrho=-0.37)$, suggesting that a lower activity of the plant photosynthetic machinery served to maintain the plant RWC. 
The LWP, in turn, result was positively associated to the plant height $(\mathrm{PH})$ and the specific leaf area (SLA) ( $\varrho=0.49$ and $\varrho=0.69$, respectively), indicating that a decrease in the plant size and leaf area per unit of dry matter contributed to the lowering of the osmic potential through the concentration of the cells' fluids. The SLA result was negatively correlated to the SPAD index, suggesting that an increase in leaf thickness (i.e., a decrease in the SLA) may have favoured chlorophyll concentration.

The SLA and $\mathrm{PH}$, in turn, results were positively correlated to the $\mathrm{Fv}^{\prime} / \mathrm{Fm}^{\prime}$, indicating a reduction in the photosystem II photochemical efficiency in parallel with the whole plant size.

We further explored the associations among traits with Principal Component Analysis (PCA), to assess the strength and direction of correlations between the original traits and the extracted Principal Components (PCs).

The first three PCs, explaining $72 \%$ of the total variance (eigenvalues reported in Table S7 of the Supplementary Materials), were used for PCA interpretation. The correlation coefficients were calculated between the PCs and each quantitative (the 24 physiological traits) and qualitative, i.e., categorical, variables (the four Atriplex genotypes and the two water treatments). The associated $p$-values were computed to rank the variables according to their relevance (Table S8 of the Supplementary Materials).

The correlation circle and the PCA biplot of variables are reported in Figure 7.
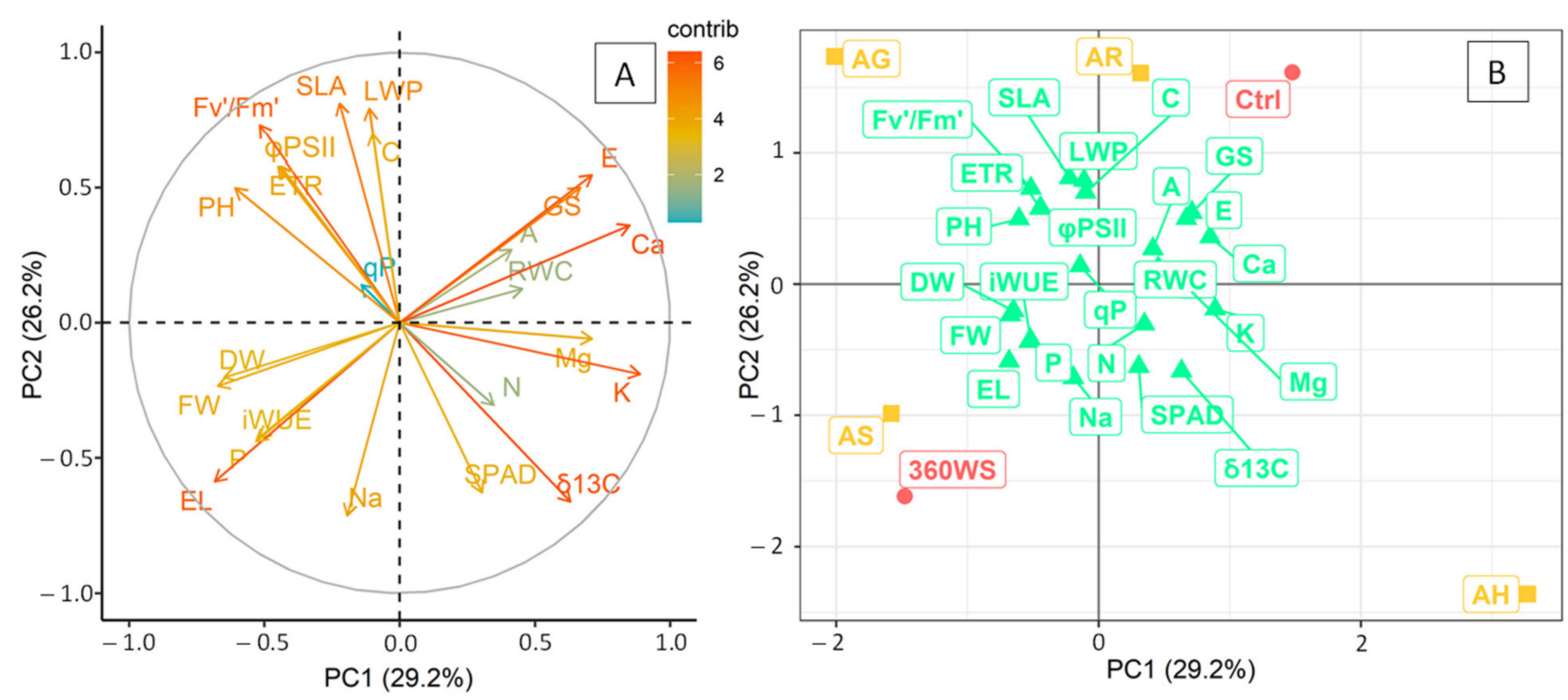

Figure 7. (A) PCA correlation circles; the increasing arrows' lengths and shades of colour from light blue to red indicate the increasing contribution of variables to the definition of the first two principal components; (B) PCA biplot of variables. Yellow squares show the barycentres of the four Atriplex genotypes (AG, AR, AS, and AH), the red points show the barycentres of the two salinity treatments (Ctrl and 360 WS), and the green triangles show the quantitative variables, i.e., the 24 measured traits.

PC1 synthesised the direct inter-relations involving plant gas exchanges, content of the main favourable cations, and plant growth. We found the strongest positive correlations with PC1 for K concentration (0.89), Ca concentration (0.85), Mg concentration (0.71), $\mathrm{E}(0.71)$, GS $(0.67), \delta^{13} \mathrm{C}(0.63)$, and in contrast, the strongest negative correlation for $\mathrm{EL}(-0.68)$, FW (-0.67), and PH (-0.60).

PC2 synthesised the direct inter-relations involving Na content, plant water potential, and the PSII photochemical activity. The PC2 showed the strongest correlation with the SLA (0.81), LWP (0.79), Fv' / Fm' (0.73), C concentration (0.70), ФPSII (0.58), ETR (0.57), $\mathrm{E}(0.68)$, and GS (0.64), and the strongest negative correlations with $\mathrm{Na}(-0.71)$ and the $\delta^{13} \mathrm{C}(-0.66)$.

PC3 summarised the inter-relations involving plant growth, $\mathrm{Na}$ and $\mathrm{N}$ concentration, and chlorophyll fluorescence. The PC3 showed the highest positive correlation with the 
qP (0.81), N (0.64), ФPSII (0.61), and ETR (0.61), and the highest negative correlation with the C $(-54)$, SPAD $(-0.54)$, and DW $(-0.49)$.

The position of the barycentres (Figure 7B) of the three A. hortensis cultivars showed a modest gap from $A$. halimus (AH). AH barycentre, indeed, was in the lower-right quadrant in the same direction of $\delta \mathrm{C}$, which is the parameter that mainly differentiated it from the other $\mathrm{C} 3$ species. AH, then, together with A. hortensis cv. scarlet (AS), were the genotypes showing the highest content of chlorophyll (SPAD value). Furthermore, AH had the same positive direction as the RWC, being the species showing the highest RWC under salinity.

$A$. hortensis cv. scarlet barycentre is in the lower-left quadrant in the same direction as the FW, DW, EL, and P, and together with the barycentre of the 360 WS treatment, as it was the species showing the highest value of these parameters under salinity.

The A. hortensis cv. green (AG) barycentre was located in the upper-right quadrant, being that showing the highest value in the fluorescence parameters despite salinity.

The proximity of the $A$. hortensis cv. red (AR) barycentre to the AG barycentre suggests their greater mutual similarity than the other two species.

The barycentre of the Ctrl treatments was located in the same direction as the gas exchange parameters, in the opposite quadrant of the fresh weight and water content parameters.

\subsection{FT-IR Spectroscopy}

In order to obtain a detailed indication of the structural changes in the samples due to saline stress, the interval between 1800 and $400 \mathrm{~cm}^{-1}$ was shown (Figure 8). In general, all the spectra displayed similar functional groups, although the relative intensity decreased in the presence of $\mathrm{NaCl}$.

A weak band at $1733 \mathrm{~cm}^{-1}$ is attributable to the uronic esters and acetyl groups of hemicelluloses, or the ester bonds of the carboxyl groups of the ferulic and $p$-coumaric acids of lignin [62]. In all the spectra, the band at $1630 \mathrm{~cm}^{-1}$ may be due to the Amide I $(\mathrm{C}=\mathrm{O})$ of proteins, unesterified uronic acids (-COO-) [63], and aromatic skeletal vibrations. Additional bands at $1550(\mathrm{~N}-\mathrm{H})$ and $1240(\mathrm{C}-\mathrm{N}) \mathrm{cm}^{-1}$ may be assigned to Amide II and Amide III bands, respectively. The broad shoulder at $1430-40 \mathrm{~cm}^{-1}$ was attributed to the $\mathrm{CH}_{2}$ bending of cellulose and lignin. The band at $1379-69 \mathrm{~cm}^{-1}$ was assigned to O-H bending [63]. The absorbance at $1320 \mathrm{~cm}^{-1}$ is typical of the aromatic skeletal vibrations [64] of the syringyl ring plus the guaiacyl ring, and the $\mathrm{C}=\mathrm{O}$ stretching vibration in lignin. The strong band at $1030 \mathrm{~cm}^{-1}$ was assigned to the $\mathrm{C}-\mathrm{O}-\mathrm{C}$ pyranose skeletal vibration of cellulose [65]. The appearance of the band at $900 \mathrm{~cm}^{-1}$ is typical of $\beta$-glucosidic bonds between the glucose units in cellulose [66]. The bands appearing from 1000 to $500 \mathrm{~cm}^{-1}$ may be also due to the vibrations of the Si-O group.

As the spectral profile of all the samples is dominated by cellulose bands, a significant decrease in the bands of this compound was observed under salt stress. In AG, no structural modification was found. 


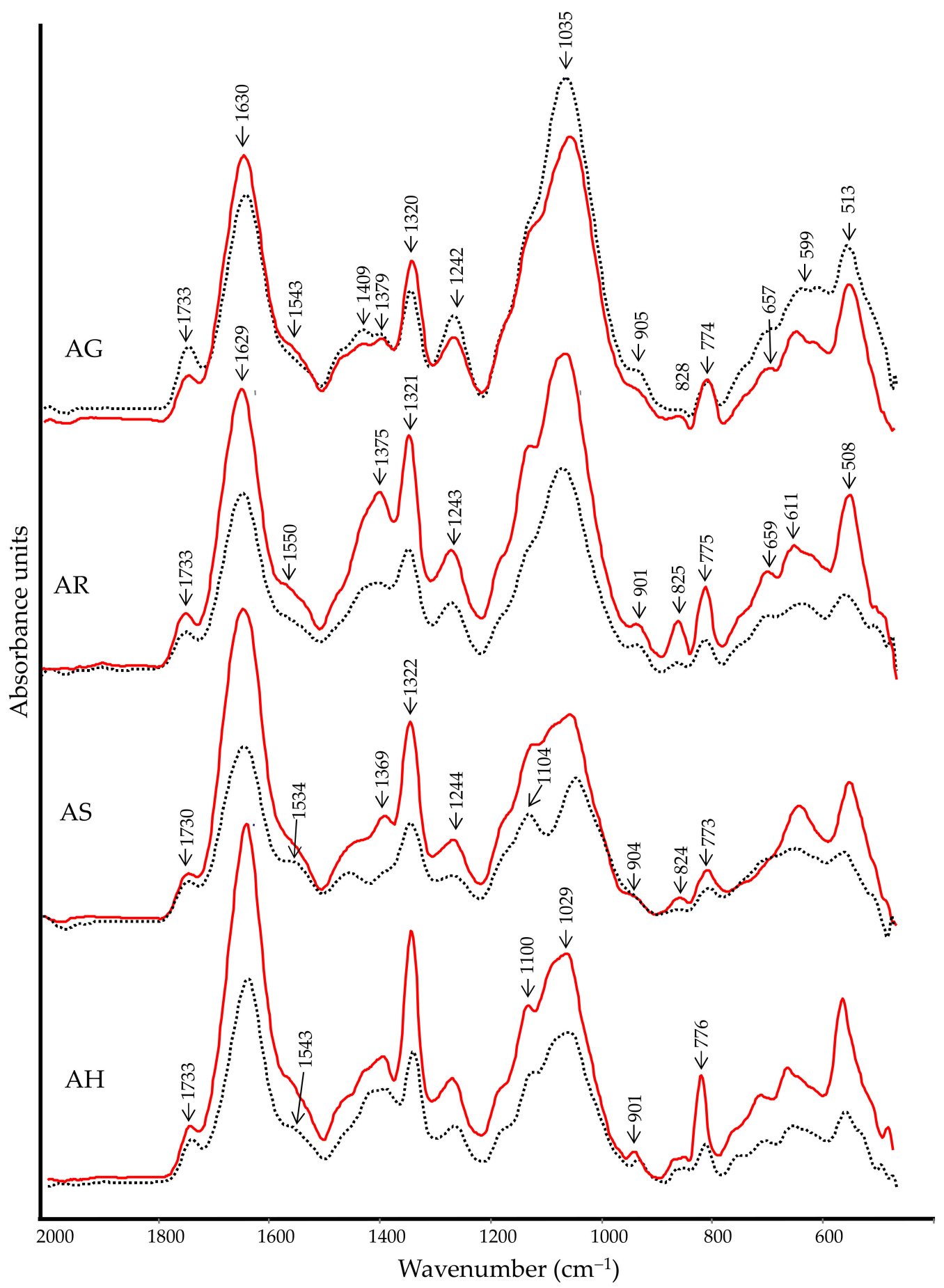

Figure 8. FTIR-ATR spectra of $A$. hortensis cv. green (AG), cv. red (AR), cv. scarlet (AS), and A. halimus (AH) samples under control (red line) and $360 \mathrm{mM}$ water salinity (black dotted line) in the 1800 and $400 \mathrm{~cm}^{-1}$ wavelengths region.

\section{Discussion}

Salt-affected soils occupy around 932 million ha of the earth's surface [67]. Through the cultivation of salt-tolerant plants, these lands may be at least partially converted into important terrestrial ecosystems, with an associated carbon sink contributing to increase the soil organic carbon stock, while providing additional space to grow food and fodder for the future population.

This work compares some physiological traits of four Atriplex genotypes common in the Mediterranean basin, whose cultivation may be part of a strategy to promote the 
restoration of saline soil organic carbon and fertility. The four genotypes showed similar behaviours under salinity, although with differences in the intensity of salinity effects.

Under Ctrl, the FW was significantly lower in A. halimus than in A. hortensis cv. green and scarlet (Figure 1). This was expected, since $A$. halimus is a perennial plant, whereas A. hortensis is an annual one, having a faster growth rate [42]. This difference was encountered also in plant height, positively correlated with plant FW (Figure 6), as A. halimus showed the lowest height. Atriplex hortensis cv. red resulted as the smallest among the three $\mathrm{C} 3$ genotypes, probably due to an intrinsic difference in its plant size.

The growth of all of the four genotypes was enhanced under $360 \mathrm{WS}$, although not significantly in A. halimus. In agreement with this, a significant increase in carbon content was detected in the three annual species but not in A. halimus under salinity (Figure 5). These results are in contrast to the findings of previous studies that found a biomass decrease in A. hortensis already at 78 [47,68] and $250 \mathrm{mM}[48,69]$, and in A. halimus already at 160 [70] and $300 \mathrm{mM}$ [71-73], while Yepes et al. [74] did not detect a biomass decrease up to $300 \mathrm{mM}$ in A. halimus.

The plant height did not vary significantly with salinity except for $A$. hortensis $\mathrm{cv}$ red. This is not in accordance with Kachout et al. [47], who observed a similar decrease both in green and red $A$. hortensis already at $78 \mathrm{mM}$.

Under control conditions, the three $\mathrm{C} 3 \mathrm{~A}$. hortensis showed values of net photosynthesis (A), stomatal conductance (GS), and transpiration rate (E) similar or even higher with respect to the C4 A. halimus (Figure 2). At 27 DAS, these parameters, especially GS and E, showed a decrease, more pronounced in the $\mathrm{C} 3$ than in the $\mathrm{C} 4$ Atriplex species (Figure 2). According to Nippert et al. [75], the higher resource use efficiency of C4 plants would allow them to remain active over a longer time and to persist through periods of resource limitations up to the late vegetative season when the $C 3$ species may have already senesced.

Under salinity, a decrease in the GS and E was observed already after 7 days from the stress initiation (Figure 2), suggesting that an effective control of the stomata opening was the primary mechanism adopted by the plants to adapt to the stress.

The higher GS and E drop compared to the control observed in A. halimus at 27 DAS confirm that the $\mathrm{C} 4$ species have a lower stomatal conductance requirement per unit of fixed $\mathrm{CO}_{2}$ [76] thanks to the ability to maintain photosynthesis also with a low internal $\mathrm{CO}_{2}$ concentration [77]. The greater stomata closure, in turn, may also explain the higher RWC values found in A. halimus than in the three A. hortensis genotypes at 27 DAS (Figure 4).

The maintenance of the levels of net photosynthesis (A) and intrinsic water use efficiency (iWUE) in all of the genotypes up to the end of the experiment indicates that the positive effect of the increased stomatal resistance to water vapour deficit due to stomata closure was higher than the detrimental effect of the increased mesophyll resistance to $\mathrm{CO}_{2}$ uptake.

This hypothesis is furtherly confirmed by the pathway in the carbon isotope ratio $\left(\delta^{13} \mathrm{C}\right)$ (Figure $\left.1 \mathrm{~F}\right)$, which decreased with $360 \mathrm{WS}$ in two of the three $\mathrm{C} 3 \mathrm{~A}$. hortensis genotypes, while it remained unchanged in the $\mathrm{C} 4 \mathrm{~A}$. halimus.

The carbon isotope ratio, indeed, is related to the stomatal conductance, as a higher ${ }^{13} \mathrm{C}$ discrimination occurs when the stomata are open [78]. A lower ${ }^{13} \mathrm{C}$ discrimination (i.e., less negative $\delta^{13} \mathrm{C}$ values), therefore, indicates the closure of the stomata and is associated with an increased iWUE [79].

The $\delta^{13} \mathrm{C}$ to iWUE relationship is easily demonstrated in the C3 species [80], because of the larger discrimination toward the heavier ${ }^{13} \mathrm{CO}_{2}$ molecule with respect to the lighter ${ }^{12} \mathrm{CO}_{2}$, resulting from Rubisco fractionation [81]. The relationship is found also in the C4 species, but to a lesser degree because of the smaller fractionation during Rubisco carboxylation [80]. C3 plants, indeed, have $\delta^{13} \mathrm{C}$ values between -32.6 and $-19.2 \%$, while C4 plants between -10.4 and $-16.6 \%$ [ [82].

The $\delta^{13} \mathrm{C}$ increase with 360 WS observed in the C3 genotypes confirms the salinityinduced increase in stomata resistance that, in turn, augmented the plant iWUE. 
Not surprisingly, the $\mathrm{C} 4 \mathrm{~A}$. halimus ${ }^{13} \mathrm{C}$ discrimination appeared to be less sensitive to salinity, although previous studies on the C4 Atriplex confertifolia [83] and A. lentiformis [84] showed a $\delta^{13} \mathrm{C}$ decrease under salinity.

Despite the significant GS and E reductions already at 7 DAS, the mild, albeit significant, effects of salinity on the PSII photochemistry were detected only at 27 DAS (Figure 3).

High external $\mathrm{NaCl}$ concentrations could harm thylakoid membranes by denaturing the lipid bilayer and lipid-protein associations, thus impairing the electron transport chain [85]. Furthermore, salinity-induced stomata closure may lead to a reduction in the proportion of opened reaction centres, thereby reducing the photochemical quenching coefficient (qP) [86]. However, the absence of these symptoms, proved by the almost unchanged $\Phi P S I I, \mathrm{Fv}^{\prime} / \mathrm{Fm}^{\prime}, \mathrm{qP}$, and ETR values, indicates that there were no serious damages to PSII machinery under 360 WS. On the contrary, the slight increase in Fv' $/ \mathrm{Fm}^{\prime}$ and ETR in A. hortensis cv. scarlet may confirm the association of red plant pigment with an improved salinity tolerance $[87,88]$.

Unlike previous studies that showed reduced pigment content in A. halimus [89] and A. hortensis [47] under salt stress, we did not observe salinity effects on the chlorophyll content in any of the four Atriplex genotypes. The negative correlation between the SPAD and the SLA (Figure 6) may in part explain this phenomenon, suggesting that a possible salt-induced reduction in chlorophyll may have been counterbalanced by the reduction in the leaf area, resulting in the unchanged concentration of the pigment.

Under salinity, the restricted water availability and the necessity to save water led to a reduced leaf area per unit of dry weight and an increased leaf thickness. In fact, the thicker cell walls and the increased concentration of osmolytes have been shown to enhance the cellular hydration maintenance, helping to overcome the salinity-induced osmotic imbalance [90]. In our experiment, this was confirmed by the positive correlation found between the SLA and the leaf water potential (LWP) (Figure 6), which suggests that a decrease in the SLA (i.e., in leaf area per unit of dry weight) contributed to the LWP lowering and, hence, to the cell osmotic adjustment.

The electrolyte leakage (EL) is a useful indicator of ROS production in plants subjected to salinity and enables us to evaluate the membrane injury caused by lipid peroxidation [91]. Thus, the results obtained in this study suggest that Atriplex membrane integrity was affected by 360 WS, and that $A$. halimus and A. hortensis cv. green were the genotypes most prone to oxidative stress. The negative correlation between the EL, GS, and E (Figure 6) is an indication that a reduced intracellular $\mathrm{CO}_{2}$ concentration under salinity favoured the formation of ROS threatening the membrane stability.

Similarly, Nedjimi et al. [71] and Paulino et al. [92] observed an EL increase in A. halimus and A. nummularia under 100 and $300 \mathrm{mM} \mathrm{NaCl}$, respectively.

Nevertheless, although Na concentration was positively correlated to EL (Figure 6), the absence of toxic $\mathrm{NaCl}$ effects on the plant photosystems indicates that the plant was able to keep Na compartmentalisation. Hence, in this case, we may assume that the high EL values may not be considered a sign of damaged plasma membranes, but rather of an NaCl-induced efflux of K [93,94]. Indeed, according to Demidchik et al. [94], under environmental stress conditions, the cytosolic $\mathrm{K}$ efflux plays a role in the metabolic switch by inhibiting consumptive anabolic reactions and stimulating energy-releasing catabolic processes that are necessary for stress adaptation and cell membrane reparation.

However, the absence of salinity effects on the K content in all of the four genotypes proves the Atriplex's ability to keep a selective K uptake also in conditions of high external Na concentration $[95,96]$.

All of the four genotypes already showed a leaf water potential (LWP) decrease after 7 days from the salt stress initiation, with $A$. hortensis cv. green and A. halimus reaching the lowest LWP levels at 27 DAS (Figure 4). As shown in the PCA correlation circle, the $\mathrm{Na}$ concentration was inversely correlated to the LWP, suggesting that an increase in the former caused a decrease in the latter. A higher uptake of Na under saline conditions 
is a common condition in many Atriplex species whose cells are able to use Na for the maintenance of cellular osmotic potential under high salinity $[97,98]$

Furthermore, the LWP appeared inversely correlated to the $\mathrm{N}$ concentration (Figure 7). Indeed, several nitrogen-containing compounds are accumulated in plants exposed to salinity $[93,95]$. These compounds contribute to the osmotic adjustment and scavenging of free radicals, favouring the maintenance of cellular macromolecules and $\mathrm{pH}$. In our study, a significant increase in $\mathrm{N}$ content was detected in the two red leaved $A$. hortensis genotypes, and this may also be related to their higher content in betacyanins, a class of pigments constituted by nitrogen-containing phenols that also play a key antioxidant role.

The increase in the phosphate concentration under salinity (Figure 5) and its positive correlation with $\mathrm{Na}$ (Figure 6) reveal, as well, the involvement of this anion in Atriplex leaf osmotic adjustment and indicate the ability of this species to augment selective phosphate uptake under high external $\mathrm{NaCl}$ concentrations [98]. In fact, salinisation has been found to increase the plant $P$ requirement, likely due its major role in the energy transfer system, in the carbohydrate partitioning and transport, and in the constitution of most enzymes [99].

Finally, FTIR spectroscopy was used for a collective screening of the changes in carbohydrates, proteins, and cell wall components during salt stress. Overall, the spectra profile of all the samples between 1800 and $400 \mathrm{~cm}^{-1}$ was dominated by cellulose bands (Figure 8). Salt stress, indeed, can indirectly affect cell wall properties.

The absorption bands at 1743, 1430-40, 1320' and $1033 \mathrm{~cm}^{-1}$ most closely reflect the presence of pectin, lignin, and cellulose. These bands decreased in all the Atriplex genotypes under saline stress, in particular in AS and AH.

Based on these results, we can infer that cell wall biosynthesis was sensitive to salinity. Similarly, Wang et al. [100] observed a reduced cell wall lignification in Atriplex prostrata under salinity due to a possible substitution of lignin with extensin during salt stress adaptation. The same was observed in the Chenopodiaceae halophyte Suaeda maritima [101].

The decrease in the Ca content (Figure 5), probably due to $\mathrm{Na}$ competition, may be among the causes of the change in the cell wall structure. Calcium ions, indeed, are involved in the stabilisation of the cell wall structure and control of the wall enzymes' activities.

A general remark, however, is that salinity may increase lignification at root level, while it decreases it at stem level [102].

Proteins, as well, are involved in the maintenance of the cell wall structure and play a major role in the cell's physiological functions and homeostasis.

The interpretation of protein status as means to assess the degree of salt tolerance of plants should, however, be considered with caution, as the relationship between protein status and salinity is not always entirely conclusive. As reported by Ashraf and Harris [103], in some studies, a higher soluble protein content was observed in salt-tolerant species than in salt-sensitive species, while other studies found a decrease or no change in the protein content under saline conditions, regardless of the degree of tolerance of the surveyed species.

In our study, the amide reduction (Figure 8) was not supported by the $\mathrm{N}$ content (Figure 5), which was higher under salt stress conditions. However, we cannot exclude the possibility that the greater contribution of the band at $1630 \mathrm{~cm}^{-1}$ may be due to the uronic acid and aromatic ring vibrations, confirming that the Atriplex cell wall composition changed in response to salinity.

By considering that the carbohydrates region between 1100 and $900 \mathrm{~cm}^{-1}$ decreased from $\mathrm{AR}$ to $\mathrm{AH}$, we can also deduce that carbohydrates contributed only modestly to osmoregulation. Indeed, as stated by Bennert et al. [104], inorganic ions ( $\mathrm{Na}, \mathrm{K}, \mathrm{Cl})$ and oxalate, an organic acid, are the main osmotically active solutes in Atriplex spp., while soluble carbohydrates, amino acids, and other organic acids are scarcely involved in the ionic balance maintenance. 


\section{Conclusions}

Both Atriplex halimus and A. hortensis thrived under salinity, as the improved plant growth demonstrates. This is apparently due to mechanisms of physiological adaptation (reduced stomatal conductance (GS) and transpiration (E)) enabling the two species to preserve moisture and improve water use efficiency.

In this respect, $A$. halimus was shown to be a slightly better performer than $A$. hortensis, thanks to the C4 vs. C3 photosynthetic pathway allowing the former species to maintain net photosynthesis despite the stronger GS and E drop under salinity. This is further supported by a stronger drop in the leaf water potential under salinity, allowing $A$. halimus to maintain a higher relative water content.

The results obtained in this study indicate both Atriplex species to be potentially suited for cultivation in marginal/abandoned saline areas, thereby contributing to soil carbon sequestration, which is the premise for the agricultural reclamation of these areas. In this strategy, the perennial A. halimus ensures a slower but longer lasting soil canopy coverage thanks to better plant homeostasis in the face of salinity, whereas the scarlet leaved genotype of $A$. hortensis is expected to provide faster soil coverage and higher biomass production.

Supplementary Materials: The following are available online at https:/ / www.mdpi.com/article/10 .3390/agronomy11101967/s1; Table S1: Effects of halophyte genotype (HG) and the four (Ctrl, 90, $180,360 \mathrm{mM} \mathrm{NaCl}$ ) water salinity levels (WS) on the physiological traits at seven days from the salt stress initiation (7 DAS). Significance codes: $\mathrm{ns},(+),{ }^{*},{ }^{* *}$, and ${ }^{* * *}$ mean, respectively, not significant and significant at $p \leq 0.1, p \leq 0.05, p \leq 0.01$, and $p \leq 0.001$. Different letters indicate significant differences at $p \leq 0.05(n=4)$; Table S2: Effects of halophyte genotype (HG) and the four (Ctrl, 90, $180,360 \mathrm{mM} \mathrm{NaCl}$ ) water salinity levels (WS) on the physiological traits at twenty-seven days from the salt stress initiation (27 DAS). Significance codes: ns, $(+),{ }^{*}, * *$ and ${ }^{* * *}$ mean, respectively, not significant and significant at $p \leq 0.1, p \leq 0.05, p \leq 0.01$, and $p \leq 0.001$. Different letters indicate significant differences at $p \leq 0.05(n=4)$; Table S3: Effects of halophyte genotype (HG) and the four (Ctrl, 90, 180, $360 \mathrm{mM} \mathrm{NaCl}$ ) water salinity levels (WS) on physiological traits, biomass, and element content at twenty-seven days from the salt stress initiation (27 DAS). Significance codes: ns, $(+)$, $*, * *$, and ${ }^{* *}$ mean, respectively, not significant and significant at $p \leq 0.1, p \leq 0.05, p \leq 0.01$, and $p \leq 0.001$. Different letters indicate significant differences at $p \leq 0.05(n=4)$; Table S4: Effects of halophyte genotype (HG) and the two corner (Ctrl and $360 \mathrm{mM} \mathrm{NaCl}$ ) water salinity levels (WS) on the physiological traits, biomass, and element content at twenty-seven days from the salt stress initiation (27 DAS). Significance codes: $\mathrm{ns},(+),{ }^{*}, * *$, and ${ }^{* * *}$ mean, respectively, not significant and significant at $p \leq 0.1, p \leq 0.05, p \leq 0.01$, and $p \leq 0.001$. Different letters indicate significant differences at $p \leq 0.05(n=4)$; Table S5: Effects of halophyte genotype (HG) and the two corner (Ctrl and $360 \mathrm{mM}$ $\mathrm{NaCl}$ ) water salinity levels (WS) on the physiological traits at seven days from the salt stress initiation (7 DAS). Significance codes: $\mathrm{ns},(+),{ }^{*}, * *$, and ${ }^{* * *}$ mean, respectively, not significant and significant at $p \leq 0.1, p \leq 0.05, p \leq 0.01$, and $p \leq 0.001$. Different letters indicate significant differences at $p$ $\leq 0.05(n=4)$; Table S6: Effects of halophyte genotype (HG) and the two corner (Ctrl and $360 \mathrm{mM}$ $\mathrm{NaCl}$ ) water salinity levels (WS) on the physiological traits at twenty-seven days from the salt stress initiation (27 DAS). Significance codes: $\mathrm{ns},(+))^{*}, * *$, and ${ }^{* * *}$ mean, respectively, not significant and significant at $p \leq 0.1, p \leq 0.05, p \leq 0.01$, and $p \leq 0.001$. Different letters indicate significant differences at $p \leq 0.05(n=4)$; Table S7. Eigen analysis of the PCA correlation matrix; Table S8. Correlation coefficients between quantitative and categorical variables, and the first three PCs. The PCs were computed using 32 input data.

Author Contributions: Conceptualisation, R.C., C.L., and L.B.; methodology, R.C. and C.L.; software, R.C.; validation, L.B.; formal analysis, R.C.; investigation, R.C., L.M., A.C., P.G., and A.S.; resources, L.B., L.M., and A.S.; data curation, R.C.; writing-original draft preparation, R.C.; writing-review and editing, L.B. and A.C.; visualisation, R.C.; supervision, L.B.; All authors have read and agreed to the published version of the manuscript.

Funding: This research received no external funding.

Institutional Review Board Statement: Not applicable. 
Informed Consent Statement: Not applicable.

Data Availability Statement: Data is contained within the article or supplementary material.

Conflicts of Interest: The authors declare no conflict of interest.

\section{References}

1. United Nation. World Population Prospects 2019: Highlights (ST/ESA/SER.A/423); United Nation-Department of Economics and Social Affairs, Population Division: New York, NY, USA, 2019.

2. Hunter, M.C.; Smith, R.G.; Schipanski, M.E.; Atwood, L.W.; Mortensen, D.A. Agriculture in 2050: Recalibrating targets for sustainable intensification. Bioscience 2017, 67, 386-391. [CrossRef]

3. Lal, R. Enhancing crop yields in the developing countries through restoration of the soil organic carbon pool in agricultural lands. Land Degrad. Dev. 2006, 17, 197-209. [CrossRef]

4. Schjønning, P.; Jensen, J.L.; Bruun, S.; Jensen, L.S.; Christensen, B.T.; Munkholm, L.J.; Oelofse, M.; Baby, S.; Knudsen, L. The Role of Soil Organic Matter for Maintaining Crop Yields: Evidence for a Renewed Conceptual Basis. Adv. Agron. 2018, 150, 35-79.

5. Godde, C.M.; Thorburn, P.J.; Biggs, J.S.; Meier, E.A. Understanding the impacts of soil, climate, and farming practices on soil organic carbon sequestration: A simulation study in Australia. Front. Plant Sci. 2016, 7, 1-15. [CrossRef] [PubMed]

6. Blanco-Canqui, H.; Shapiro, C.A.; Wortmann, C.S.; Drijber, R.A.; Mamo, M.; Shaver, T.M.; Ferguson, R.B. Soil organic carbon: The value to soil properties. J. Soil Water Conserv. 2013, 68, 129A-134A. [CrossRef]

7. Lal, R. Soils as source and sink of environmental carbon dioxide. In Molecular Environmental Soil Science at the Interfaces in the Earth's Critical Zone; Xu, J., Huang, P.M., Eds.; Springer: Berlin/Heidelberg, Germany, 2010; pp. 11-12. ISBN 978-3-642-05297-2.

8. Oelkers, E.H.; Cole, D.R. Carbon dioxide sequestration: A solution to a global problem. Elements 2008, 4, 305-310. [CrossRef]

9. Lorenz, K.; Lal, R. Carbon Sequestration in Agricultural Ecosystems; Springer: Dordrecht, The Netherlands, 2018; ISBN 9783319923185.

10. Ruddiman, W.F. The anthropogenic greenhouse era began thousands of years ago. Clim. Chang. 2003, 61, 261-293. [CrossRef]

11. Lal, R.; Smith, P.; Jungkunst, H.F.; Mitsch, W.J.; Lehmann, J.; Ramachandran Nair, P.K.; McBratney, A.B.; De Moraes Sá, J.C.; Schneider, J.; Zinn, Y.L.; et al. The carbon sequestration potential of terrestrial ecosystems. J. Soil Water Conserv. 2018, 73, 145A-152A. [CrossRef]

12. Food and Agriculture Organization of the United Nations. RECSOIL-Recarbonization of Global Soils; FAO: Rome, Italy, 2019.

13. Torn, M.S.; Swanston, C.W.; Castanha, C.; Trumbore, S.E. Storage and Turnover of Organic Matter in Soil; Wiley: Hoboken, NJ, USA, 2009; ISBN 9780470413005.

14. Abbas, A.; Khan, S.; Hussain, N.; Hanjra, M.A.; Akbar, S. Characterizing soil salinity in irrigated agriculture using a remote sensing approach. Phys. Chem. Earth 2013, 55-57, 43-52. [CrossRef]

15. Glenn, E.; Squires, V.; Olsen, M.; Frye, R. Potential for carbon sequestration in the drylands. Water Air Soil Pollut. 1993, 70, $341-355$. [CrossRef]

16. Ritson, P.; Clarke, M.; Killen, A.; Jeffery, S. Testing Carbon Farming Opportunities for Salinity Management; Department of Primary Industries and Regional Development: Perth, Australia, 2015; ISBN 9780992332310.

17. Liu, X.; Ruecker, A.; Song, B.; Xing, J.; Conner, W.H.; Chow, A.T. Effects of salinity and wet-dry treatments on C and N dynamics in coastal-forested wetland soils: Implications of sea level rise. Soil Biol. Biochem. 2017, 112, 56-67. [CrossRef]

18. Setia, R.; Gottschalk, P.; Smith, P.; Marschner, P.; Baldock, J.; Setia, D.; Smith, J. Soil salinity decreases global soil organic carbon stocks. Sci. Total Environ. 2013, 465, 267-272. [CrossRef] [PubMed]

19. Yang, J.; Zhan, C.; Li, Y.; Zhou, D.; Yu, Y.; Yu, J. Effect of salinity on soil respiration in relation to dissolved organic carbon and microbial characteristics of a wetland in the Liaohe River estuary, Northeast China. Sci. Total Environ. 2018, 642, 946-953. [CrossRef] [PubMed]

20. Mishra, A.; Sharma, S.D. Leguminous trees for the restoration of degraded sodic wasteland in Eastern Uttar Pradesh, India. L. Degrad. Dev. 2003, 14, 245-261. [CrossRef]

21. Qadir, M.; Noble, A.D.; Oster, J.D.; Schubert, S.; Ghafoor, A. Driving forces for sodium removal during phytoremediation of calcareous sodic and saline-sodic soils: A review. Soil Use Manag. 2005, 21, 173-180. [CrossRef]

22. Qadir, M.; Oster, J.D.; Schubert, S.; Noble, A.D.; Sahrawat, K.L. Phytoremediation of sodic and saline-aodic Soils. In Advances in Agronomy; Elsevier: Amsterdam, The Netherlands, 2007; Volume 96, pp. 197-247. ISBN 0123742064.

23. Wong, V.N.L.; Murphy, B.W.; Koen, T.B.; Greene, R.S.B.; Dalal, R.C. Soil organic carbon stocks in saline and sodic landscapes. Aust. J. Soil Res. 2008, 46, 378-389. [CrossRef]

24. Glenn, E.P.; Lieth, H.; Hodges, C.N.; Pielke, R.; Pitelka, L. Growing halophytes to remove carbon from the atmosphere. Environ. Washingt. 1992, 34, 40-44. [CrossRef]

25. Calone, R.; Bregaglio, S.; Sanoubar, R.; Noli, E.; Lambertini, C.; Barbanti, L. Physiological adaptation to water salinity in six wild halophytes suitable for mediterranean agriculture. Plants 2021, 10, 309. [CrossRef] [PubMed]

26. Le Houérou, H.N. Salt-tolerant plants for the arid regions of the Mediterranean isoclimatic zone. In Towards the Rational Use of High Salinity Tolerant Plants; Springer: Dordrecht, The Netherlands, 1993; Volume I, pp. 403-422.

27. Walden, L.L.; Harper, R.J.; Sochacki, S.J.; Montagu, K.D.; Wocheslander, R.; Clarke, M.; Ritson, P.; Emms, J.; Davoren, C.W.; Mowat, D.; et al. Mitigation of carbon using Atriplex nummularia revegetation. Ecol. Eng. 2017, 106, 253-262. [CrossRef] 
28. Zucca, C.; Arrieta Garcia, S.; Deroma, M.; Madrau, S. Organic carbon and alkalinity increase in topsoil after rangeland restoration through atriplex nummularia plantation. Land Degrad. Dev. 2016, 27, 573-582. [CrossRef]

29. Asgari, H.R.; SolaimaniSardo, M.; Kiani, F.; Heshmati, G.A. Effects of planting haloxylon and atriplex on soil carbon sequestration in desertified land reclamation (Case Study: Kerman Province). Int. J. Environ. Resour. Res. 2013, 1, 131-140.

30. Roya, V.; Reza, A.H.; Majid, O.; Bairam, K.C. Evaluating the relationship between atriplex halimus density with soil carbon sequestration (Case study: Semi-Arid Rangeland of Incheborun, Golestan Province). J. Range Watershed Manag. 2015, 68, 173-180.

31. Vazirian, R.; Ownegh, M. Effect of Atriplex halimus on Indicators of soil erodibility (Case Study: Incheborun, Golestan Province). Int. J. Adv. Biol. Biomed. Res. 2014, 2, 1985-1990.

32. Walker, D.J.; Lutts, S.; Sánchez-García, M.; Correal, E. Atriplex halimus L.: Its biology and uses. J. Arid Environ. 2014, 100-101, 111-121. [CrossRef]

33. Bienes, R.; Marques, M.J.; Ruiz-colmenero, M.; Arevalo, D.; Sastre, B. Effects of shrub revegetation with Atriplex halimus L. and Retama sphaerocarpa L. in gypsiferous soils. Influence in soil properties. In Proceedings of the Conference: EGU General Assembly 2014, Vienna, Austria, 27 April-2 May 2014; Volume 16, p. 2153.

34. Abdel-Fattah, M.K. Potential use of halophytes in combination with gypsum to reclaim and restore saline-sodic soils in Egypt. Malays. J. Soil Sci. 2015, 19, 131-139.

35. Gharaibeh, M.A.; Eltaif, N.I.; Albalasmeh, A.A. Reclamation of highly calcareous saline sodic soil using Atriplex halimus and by-product gypsum. Int. J. Phytoremediation 2011, 13, 873-883. [CrossRef]

36. Al-Satari, Y.; Al-Dein Al-Ramamneh, E.; Ayad, J.; Dalbouh, M.A.; Amayreh, I.; Khreisat, Z. Impact of seedling age on the survival and productivity of Atriplex halimus shrubs in drought-affected rangelands of Jordan. Rangel. J. 2018, 40, 287-296. [CrossRef]

37. Osman, A.E.; Bahhady, F.; Hassan, N.; Ghassali, F.; Al Ibrahim, T. Livestock production and economic implications from augmenting degraded rangeland with Atriplex halimus and Salsola vermiculata in northwest Syria. J. Arid Environ. 2006, 65, 474-490. [CrossRef]

38. Abu-Zanat, M.M.W.; Al-Ghaithi, A.K.; Akash, M.W. Effect of Planting Atriplex seedlings in micro-catchments on attributes of natural vegetation in arid rangelands. J. Arid Environ. 2020, 180, 104199. [CrossRef]

39. Tapia, Y.; Diaz, O.; Pizarro, C.; Segura, R.; Vines, M.; Zúñiga, G.; Moreno-Jiménez, E. Atriplex atacamensis and Atriplex halimus resist As contamination in Pre-Andean soils (northern Chile). Sci. Total Environ. 2013, 450-451, 188-196. [CrossRef]

40. Martínez-Fernández, D.; Walker, D.J. The effects of soil amendments on the growth of Atriplex halimus and Bituminaria bituminosa in heavy metal-contaminated soils. Water. Air Soil Pollut. 2012, 223, 63-72. [CrossRef]

41. Manousaki, E.; Kalogerakis, N. Phytoextraction of Pb and Cd by the Mediterranean saltbush (AtripLex halimus L.): Metal uptake in relation to salinity. Environ. Sci. Pollut. Res. 2009, 16, 844-854. [CrossRef] [PubMed]

42. Suaire, R.; Durickovic, I.; Framont-Terrasse, L.; Leblain, J.Y.; De Rouck, A.C.; Simonnot, M.O. Phytoextraction of $\mathrm{Na}^{+}$and $\mathrm{Cl}^{-}$by Atriplex halimus L. and Atriplex hortensis L.: A promising solution for remediation of road runoff contaminated with deicing salts. Ecol. Eng. 2016, 94, 182-189. [CrossRef]

43. Acosta, J.A.; Abbaspour, A.; Martínez, G.R.; Martínez-Martínez, S.; Zornoza, R.; Gabarrón, M.; Faz, A. Phytoremediation of mine tailings with Atriplex halimus and organic/inorganic amendments: A five-year field case study. Chemosphere 2018, 204, 71-78. [CrossRef] [PubMed]

44. Pérez-Esteban, J.; Escolástico, C.; Ruiz-Fernández, J.; Masaguer, A.; Moliner, A. Bioavailability and extraction of heavy metals from contaminated soil by Atriplex halimus. Environ. Exp. Bot. 2013, 88, 53-59. [CrossRef]

45. Al-Satari, Y.A.R. Intercropping of Atriplex halimus, Salsola vermiculata and Barley for sustainable feed production under rangeland conditions in Jordan. IMPACT Int. J. Res. Appl. Nat. Soc. Sci. (IMPACT IJRANSS) 2014, 2, 67-72.

46. Ghassali, F.; Osman, A.E.; Singh, M.; Norton, B.; Louhaichi, M.; Tiedeman, J. Potential use of Mediterranean saltbush (Atriplex halimus L.) in alley cropping in the low rainfall-cropping zone of Northwest Syria. Range Manag. Agrofor. 2011, 32, 1-8.

47. Kachout, S.S.; Ben Mansoura, A.; Jaffel, K.; Leclerc, J.C.; Rejeb, M.N.; Ouerghi, Z. The effect of salinity on the growth of the halophyte Atriplex hortensis (Chenopodiaceae). Appl. Ecol. Environ. Res. 2010, 7, 319-332. [CrossRef]

48. Wilson, C.; Lesch, S.M.; Grieve, C.M. Growth stage modulates salinity tolerance of New Zealand spinach (Tetragonia tetragonioides Pall.) and red orach (Atriplex hortensis L.). Ann. Bot. 2000, 85, 501-509. [CrossRef]

49. Sai Kachout, S.; Leclerc, J.C.; Ben Mansoura, A.; Rejeb, M.N.; Ouerghi, Z. Effects of heavy metals on growth and bioaccumulation of the annual halophytes Atriplex hortensis and A. rosea. J. Appl. Sci. Res. 2009, 5, 746-756.

50. Rinchen, T.; Singh, N.; Bhadur, S.M. Mineral content estimation in Atriplex hortensis L., an indigenous vegetable of TransHimalayan region of Ladakh, India. Res. Crop. 2019, 20, 135-140.

51. Rinchen, T.; Singh, N. Exploring nutritional potential of Atriplex hortensis. Indian Hortic. 2015, 60, 16-17.

52. Wright, K.H.; Pike, O.A.; Fairbanks, D.J.; Huber, C.S. Composition of Atriplex hortensis, sweet and bitter Chenopodium quinoa seeds. J. Food Sci. 2002, 67, 1383-1385. [CrossRef]

53. Carlsson, R.; Clarke, E.M.W. Atriplex hortensis L. as a leafy vegetable, and as a leaf protein concentrate plant. Qual. Plant. Plant Foods Hum. Nutr. 1983, 33, 127-133. [CrossRef]

54. Khan, M.M.; Al-Mas'oudi, R.S.M.; Al-Said, F.; Khan, I. Salinity Effects on Growth, Electrolyte Leakage, Chlorophyll Content and Lipid Peroxidation in Cucumber (Cucumis sativus L.). In Proceedings of the International Conference on Food and Agricultural Sciences, Melaka, Malaysia, 7-8 October 2013; IACSIT Press: Singapore, 2013; Volume 55.

55. Smart, R.E.; Bingham, G.E. Rapid Estimates of Relative Water Content. Plant Physiol. 1974, 53, 258-260. [CrossRef] 
56. Fieller, E.C.; Pearson, E.S. Tests for rank correlation coefficients. I. Biometrika 1957, 44, 470-481. [CrossRef]

57. Fox, J.; Weisberg, S. An R Companion to Applied Regression, 3rd ed.; Sage: Thousand Oaks, CA, USA, 2019.

58. Lenth, R.V.; Buerkner, P.; Herve, M.; Love, J.; Riebl, H.; Singmann, H. Emmeans: Estimated Marginal Means, aka LeastSquares Means. R pack. Available online: https://cran.r-project.org/web/packages/emmeans/index.html (accessed on 30 June 2021).

59. Lê, S.; Josse, J.; Husson, F. FactoMineR: An R package for multivariate analysis. J. Stat. Softw. 2008, 25, 1-18. [CrossRef]

60. Wickham, H. ggplot2: Elegant Graphics for Data Analysis. Available online: https://ggplot2.tidyverse.org/reference/ (accessed on 18 June 2021).

61. Wei, T.; Simko, V. R package 'corrplot': Visualization of a Correlation Matrix. (Version 0.90). Available online: https://github. $\mathrm{com} /$ taiyun/corrplot (accessed on 21 June 2021).

62. Sun, X.F.; Xu, F.; Sun, R.C.; Fowler, P.; Baird, M.S. Characteristics of degraded cellulose obtained from steam-exploded wheat straw. Carbohydr. Res. 2005, 340, 97-106. [CrossRef] [PubMed]

63. Westworth, S.; Ashwath, N.; Cozzolino, D. Application of FTIR-ATR spectrocopy to detect salinity response in Beauty Leaf Tree (Calophyllum inophyllam L). Energy Procedia 2019, 160, 761-768. [CrossRef]

64. Zhou, G.; Taylor, G.; Polle, A. FTIR-ATR-based prediction and modelling of lignin and energy contents reveals independent intra-specific variation of these traits in bioenergy poplars. Plant Methods 2011, 7, 9. [CrossRef] [PubMed]

65. Afifi, A.A.; Youssef, R.A.; Husseiny, M.M. Fourier transform infrared spectometry study on early stage of salt stress in jujube plant. Life Sci. J. 2013, 10, 1973-1981.

66. El-Sakhawy, M.; Kamel, S.; Salama, A.; Tohamy, H.A.S. Preparation and infrared study of cellulose based amphiphilic materials. Cellul. Chem. Technol. 2018, 52, 193-200.

67. Zaman, M.; Shahid, S.; Heng, L. Guideline for Salinity Assessment, Mitigation and Adaptation Using Nuclear and Related Techniques; Springer: Cham, Switzerland, 2018; ISBN 978-3-319-96189-7.

68. Glenn, E.P.; Nelson, S.G.; Ambrose, B.; Martinez, R.; Soliz, D.; Pabendinskas, V.; Hultine, K. Comparison of salinity tolerance of three Atriplex spp. in well-watered and drying soils. Environ. Exp. Bot. 2012, 83, 62-72. [CrossRef]

69. Shannon, M.C.; Grieve, C.M. Tolerance of vegetable crops to salinity. Sci. Hortic. 1998, 78, 5-38. [CrossRef]

70. Hassine, A.B.; Lutts, S. Differential responses of saltbush Atriplex halimus L. exposed to salinity and water stress in relation to senescing hormones abscisic acid and ethylene. J. Plant Physiol. 2010, 167, 1448-1456. [CrossRef] [PubMed]

71. Nedjimi, B.; Daoud, Y. Effects of calcium chloride on growth, membrane permeability and root hydraulic conductivity in two Atriplex species grown at high (sodium chloride) salinity. J. Plant Nutr. 2009, 32, 1818-1830. [CrossRef]

72. Bouchenak, F.; Henri, P.; Benrebiha, F.Z.; Rey, P. Differential responses to salinity of two Atriplex halimus populations in relation to organic solutes and antioxidant systems involving thiol reductases. J. Plant Physiol. 2012, 169, 1445-1453. [CrossRef]

73. Ayad, J.Y. Comparative effects of $\mathrm{CaCl}_{2}$ nad $\mathrm{NaCl}$ salinity on growth and Ion partitioning of Atriplex halimus L. Agric. Sci. 2010, 37, 82-90.

74. Yepes, L.; Chelbi, N.; Vivo, J.M.; Franco, M.; Agudelo, A.; Carvajal, M.; del Martínez-Ballesta, M.C. Analysis of physiological traits in the response of Chenopodiaceae, Amaranthaceae, and Brassicaceae plants to salinity stress. Plant Physiol. Biochem. 2018, 132, 145-155. [CrossRef] [PubMed]

75. Nippert, J.B.; Fay, P.A.; Knapp, A.K. Photosynthetic traits in $\mathrm{C}_{3}$ and $\mathrm{C}_{4}$ grassland species in mesocosm and field environments. Environ. Exp. Bot. 2007, 60, 412-420. [CrossRef]

76. Sage, R.F. Synthetic evolution of $\mathrm{C}_{4}$ photosynthesis. New Phytol. 2004, 161, 341-370. [CrossRef]

77. Collatz, G.; Ribas-Carbo, M.; Berry, J. Coupled photosynthesis-stomatal conductance model for leaves of C4 plants. Funct. Plant Biol. 1992, 19, 519. [CrossRef]

78. Katschnig, D.; Broekman, R.; Rozema, J. Salt tolerance in the halophyte Salicornia dolichostachya Moss: Growth, morphology and physiology. Environ. Exp. Bot. 2013, 92, 32-42. [CrossRef]

79. Marshall, J.D.; Zhang, J. Carbon isotope discrimination and water-use efficiency in native plants of the North-Central rockies. Ecology 1994, 75, 1887-1895. [CrossRef]

80. Farquhar, G.D.; Ehleringer, R.; Hubick, K.T. Carbon isotope discrimination and photosynthesis. Annu. Rev. Plant Physiol. Plant Mol. Bioi. 1989. 1989, 40, 503-537. [CrossRef]

81. O'Leary, M.H. Carbon isotope fractionation in plants. Phytochemistry 1981, 20, 553-567. [CrossRef]

82. Basu, S.; Agrawal, S.; Sanyal, P.; Mahato, P.; Kumar, S.; Sarkar, A. Carbon isotopic ratios of modern C3-C4 plants from the Gangetic Plain, India and its implications to paleovegetational reconstruction. Palaeogeogr. Palaeoclimatol. Palaeoecol. 2015, 440, 22-32. [CrossRef]

83. Sandquist, D.R.; Ehleringer, J.R. Carbon isotope discrimination in the C4 shrub Atriplex confertifolia along a salinity gradient. Great Basin Nat. 1995, 55, 135-141.

84. Zhu, J.; Meinzer, F.C. Efficiency of C4 photosynthesis in Atriplex lentiformis under salinity stress. Aust. J. Plant Physiol. 1999, 26, 79-86.

85. Reddy, M.; Vora, A. Salinity induced changes in pigment composition and chlorophyllase activity of wheat. Indian J. Plant Physiol. 1986, 29, 331-334.

86. James, R.A.; Rivelli, A.R.; Munns, R.; Von Caemmerer, S. Factors affecting $\mathrm{CO}_{2}$ assimilation, leaf injury and growth in salt-stressed durum wheat. Funct. Plant Biol. 2002, 29, 1393-1403. [CrossRef] 
87. Li, Y.; Cui, L.; Yao, X.; Ding, X.; Pan, X.; Zhang, M.; Li, W.; Kang, X. Trade-off between leaf chlorophyll and betacyanins in Suaeda salsa in the Liaohe estuary wetland in northeast China. J. Plant Ecol. 2018, 11, 569-575. [CrossRef]

88. Polturak, G.; Heinig, U.; Grossman, N.; Battat, M.; Leshkowitz, D.; Malitsky, S.; Rogachev, I.; Aharoni, A. transcriptome and metabolic profiling provides insights into betalain biosynthesis and evolution in Mirabilis jalapa. Mol. Plant 2018, 11, 189-204. [CrossRef]

89. Boughalleb, F.; Denden, M.; Tiba, B.B. Photosystem II photochemistry and physiological parameters of three fodder shrubs, Nitraria retusa, Atriplex halimus and Medicago arborea under salt stress. Acta Physiol. Plant. 2009, 31, 463-476. [CrossRef]

90. Marron, N.; Dreyer, E.; Boudouresque, E.; Delay, D.; Petit, J.M.; Delmotte, F.M.; Brignolas, F. Impact of successive drought and re-watering cycles on growth and specific leaf area of two Populus x canadensis (Moench) clones, "Dorskamp" and "Luisa_Avanzo". Tree Physiol. 2003, 23, 1225-1235. [CrossRef]

91. Rangani, J.; Parida, A.K.; Panda, A.; Kumari, A. Coordinated changes in antioxidative enzymes protect the photosynthetic machinery from salinity induced oxidative damage and confer salt tolerance in an extreme halophyte Salvadora persica L. Front. Plant Sci. 2016, 7, 1-18. [CrossRef]

92. Paulino, M.K.S.S.; de Souza, E.R.; Lins, C.M.T.; Dourado, P.R.M.; de Leal, L.Y.C.; Monteiro, D.R.; de Rego Junior, F.E.A.; de Silva, C.U.C. Influence of vesicular trichomes of Atriplex nummularia on photosynthesis, osmotic adjustment, cell wall elasticity and enzymatic activity. Plant Physiol. Biochem. 2020, 155, 177-186. [CrossRef]

93. Mansour, M.M.F. Nitrogen containing compounds and adaptation of plants to salinity stress. Biol. Plant. 2000, 43, 491-500. [CrossRef]

94. Demidchik, V.; Straltsova, D.; Medvedev, S.S.; Pozhvanov, G.A.; Sokolik, A.; Yurin, V. Stress-induced electrolyte leakage: The role of $\mathrm{K}^{+}$permeable channels and involvement in programmed cell death and metabolic adjustment. J. Exp. Bot. 2014, 65, 1259-1270. [CrossRef]

95. Mata-González, R.; Abdallah, M.A.B.; Trejo-Calzada, R.; Wan, C. Growth and leaf chemistry of Atriplex species from Northern Mexico as affected by salt stress. Arid Land Res. Manag. 2016, 31, 57-70. [CrossRef]

96. Pan, Y.-Q.Q.; Guo, H.; Wang, S.-M.M.; Zhao, B.; Zhang, J.-L.L.; Ma, Q.; Yin, H.-J.J.; Bao, A.-K.K. The photosynthesis, Na ${ }^{+} / K^{+}$ homeostasis and osmotic adjustment of Atriplex canescens in response to salinity. Front. Plant Sci. 2016, 7, 1-14. [CrossRef]

97. Wallace, A.; Romney, E.M.; Mueller, R.T. Sodium relations in desert plants: 7 effects of sodium chloride on Atriplex polycarpa and Atriplex canescens. Soil Sci. 1982, 134, 65-68. [CrossRef]

98. Mahmood, K.; Vanderdeelen, J.; Baert, L. Growth and phosphorus uptake of Atriplex amnicola at different levels of NaCI. Biol. Plant. 1993, 35, 285-288. [CrossRef]

99. Villora, G.; Moreno, D.A.; Pulgar, G.; Romero, L. Salinity affects phosphorus uptake and partitioning in zucchini. Commun. Soil Sci. Plant Anal. 2000, 31, 501-507. [CrossRef]

100. Wang, L.; Showalter, A.M.; Ungar, I.A. Effect of salinity on growth, ion content, and cell wall chemistry in Atriplex prostrata (Chenopodiaceae). Am. J. Bot. 1997, 84, 1247-1255. [CrossRef] [PubMed]

101. Hagege, D.; Kevers, C.; Boucaud, J.; Gaspar, T. Peroxidase activities, ethylene production and lignification in relation with growth limitation in Suaeda maritima cultured in absence of NaCl. Plant Physiol. Biochem. 1988, 26, 609-614.

102. Grigore, M.; Toma, C. Histo-anatomical strategies of chenopodiaceae halophytes: Adaptive, ecological and evolutionary implications. WSEAS Trans. Biol. Biomed. 2007, 4, 204-218.

103. Ashraf, M.; Harris, P.J.C. Potential biochemical indicators of salinity tolerance in plants. Plant Sci. 2004, 166, 3-16. [CrossRef]

104. Bennert, H.W.; Schmidt, B. On the osmoregulation in Atriplex hymenelytra (Torr.) Wats. (Chenopodiaceae). Oecologia 1984, 62, 80-84. [CrossRef] 